\title{
EL SIGNIFICADO DEL CIERVO ENTRE LOS PUEBLOS PROTOHISTÓRICOS DE LA PENÍNSULA IBÉRICA
}

\author{
THE MEANING OF THE RED DEER AMONGST THE PROTOHISTORICAL PEOPLES OF THE IBERIAN \\ PENINSULA
}

\author{
MARÍA PAZ GARCÍA-GELABERT PÉREZ \\ Universidad de Valencia \\ JOSÉ Ma. BLÁZQUEZ MARTÍNEZ \\ Real Academia de la Historia
}

\begin{abstract}
Resumen. El significado del ciervo en el ideario, en las creencias de las gentes que poblaron la Península lbérica en la Protohistoria, y que por el mismo fue plasmado en la plástica en diversos soportes, es un aspecto de la investigación muy comprometido y complicado. No obstante, en este estudio intentamos abordar dicho significado a través de los dichos tiempos protohistóricos.

Palabras clave.Ciervos, iberos, celtas, Protohistoria, pintura rupestre y vascular, grabado rupestre, escultura, toréutica, musivaria, Sertorio, mitos, cervulum facere.
\end{abstract}

\begin{abstract}
The meaning of the red deer in the ideas and belief systems of the people who inhabited the Iberian Peninsula in the protohistorical period, and depicted it in various materials, is a very complicated and involved aspect of research. In this study we try to discover its meaning in the protohistoric period.

Key words. Red deer, Iberians, Celts, Protohistory, cave and vase painting, rock engraving, sculpture, stamping, Sertorius, myths, cervulum facere.
\end{abstract}

\section{PRESENTACIÓN}

Deseamos inferir el sentido del ciervo (Cervus elaphus) (Fig. 1) en la plástica-que es realmente lo que conservamos-, entre los pueblos estrictamente protohistóricos, en cuanto a su posible acepción religiosa en el más amplio alcance. Entre estos pueblos que sí lo plasmaban sobre determinados útiles o como figura aislada, con una interpretación trascendente, dinamizado por la proyección de un ideario previo; pero, por otro lado, en el aspecto doméstico, pragmático, lo perseguían, lo capturaban a base de lanzas, dardos, hachas, lazos, etc.; comían su carne, aprovechaban su pellejo, convirtiéndolo en cuero, y aprovechaban sus complejas cuernas, algunas de las cuales llegan a alcanzar $1 \mathrm{~m}$. de alto.

De una forma $u$ otra no creemos que su aparición en la plástica constituya una metáfora, es decir la adecuación de un ser material a argumentos espirituales.

Bien, acudimos precisamente a la plástica porque, como indicamos arriba, faltan textos, o cualquier otro tipo de información. $Y$ los textos que hay, y es un tema recurrente, son escasos, parcos en información, y mediatizados por presiones e ideologías diversas.

Ha de entenderse como una posibilidad cercana a la realidad, que aquellos que compu-

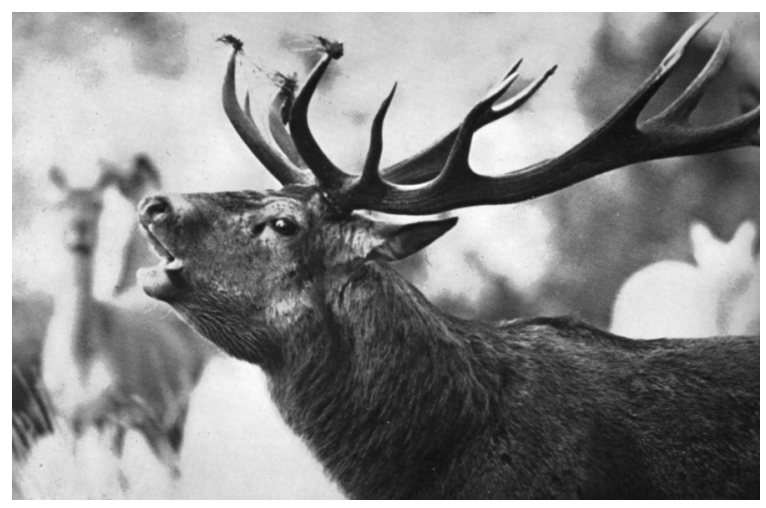

Figura 1: Cervus elaphus (Foto Rodríguez de la Fuente, 1970). 
sieron las obras, para este estudio las que contienen figuraciones de cérvidos, o a los que iba dirigida la producción, no pretendieron tanto el sentido estético, que está implícito -por regla general, se tiende a producir belleza, aunque hay desastrosas excepciones en las que el hombre precisamente la destruye- como su alcance simbólico, alegórico, mitológico, apotropaico. Bien, son estos significados, que tienen mucho que ver con el espíritu, reiteramos, los que pretendemos averiguar. Y una indicación necesaria, el trabajo ha sido realizado a partir del examen de las fotografías publicadas por diferentes investigadores, cuyos nombres se recogen, tanto en bibliografía, como, en su caso, al pie de las figuras que ilustran el texto.

Vayamos, en el transcurso de las líneas que siguen, haciendo fluir, por periodos, por largos periodos, hipótesis, no excesivamente convincentes. Todos los elementos arqueológicos de que disponemos adolecen de consistencia, no por sí mismos, sino porque en las más de las ocasiones suelen consistir en ejemplares aislados, fuera de contexto determinado.

Estructuramos la Península en dos grandes territorios para la Protohistoria lejana y para la cercana a la llegada de las tropas imperialistas cartaginesas y romanas:

1. El de las tribus autóctonas mestizadas por la etnia indoeuropea, de manera parece que intensa a partir de la fase del Bronce Final, antes más levemente. De estas tribus conservamos escasas manifestaciones plásticas para nuestro tema, excepto la contenida en las estelas funerarias tardías y poco más.

2. El de las tribus autóctonas mediterráneas y de su hinterland, influidos, sus dirigentes, por los colonizadores orientales durante el Bronce Final orientalizante, y parte del Hierro Antiguo. Poseemos información a través de escasas piezas destinadas a las clases favorecidas, bien porque fueran adquiridas mediante trueque, bien porque les fueran ofrecidas, como obsequio, por los mercaderes tirios, para granjearse su confianza.

Para siglos anteriores, como aún hay menos equipo "artístico" para articular alguna teoría, abarcamos la totalidad de Iberia, aunque ha de afirmarse que prácticamente no disponemos de dato alguno válido acerca del tema, en general, para el Calcolítico, para el Bronce Antiguo y Medio. Por lo demás, el aniconismo poderoso, es privativo de todas las tribus peninsulares, y más de las de la Protohistoria temprana. Volviendo al Bronce Final, éste se caracterizó por una cierta mayor actividad económica, social y cultural, debida, en parte, a las aportaciones humanas y culturales de gentes foráneas $\mathrm{y}$, en parte, a la evolución propia de los grupos peninsulares, lo cual, en su conjunto, conllevó un más amplio desarrollo e interrelación poblacional. Y es en esta última época de la Edad del Bronce, y únicamente en la región meridional y parte de la occidental, es decir la que estuvo en contacto más directo con los colonizadores fenicios o con sus agentes nativos -en las restantes hay un alto vacío de información al respecto del tema que manejamos, similar al existente en tiempos anteriores-, donde si podemos apoyarnos en ciertas figuras de ciervos, que debieron trascender la materialidad. Son ciervos exentos, o que adornan los jarros, los thymiateria, u otros objetos, todos o la mayor parte, fabricados en bronce y todos fabricados por los artesanos orientales, bien en talleres tirios, bien ya en talleres coloniales peninsulares.

Estos pueblos, estas culturas impregnadas de orientalismo derivan, simplificando, con el correr de los años, a la civilización ibérica, cuyos miembros levantaron grandes monumentos funerarios, en el frente de los cuales hay escenas varias entre las que aparece el ciervo.

\section{INTRODUCCIÓN}

Las sociedades prerromanas más primitivas de la Península Ibérica no fueron, ya lo apuntamos, partidarias de introducir imágenes, animales y/o humanas, en su acervo artístico, por lo menos perennes. En realidad tiende a ser una constante. De esta generalidad hemos de excluir a los clanes de cazadores/recolectores del Paleolítico Superior, a los que no incluimos, evidentemente, en la Protohistoria, pero que por constituir los primeros grupos humanos peninsulares conocidos, los tenemos en cuenta a los efectos introductorios del estudio. Ellos, al menos como consecuencia de un segmento de sus creencias, introdujeron representaciones plásticas -pintura y grabado rupestre y mueble- hasta llegar, incluso, a una acusada exuberancia y riqueza en sus expresiones artísticas. Así es, fueron los creadores del gran arte parietal cuaternario, que conoció un extraordinario esplendor en el occidente europeo, siendo su trayectoria casi idéntica a largas distancias: desde el Yonne hasta el Estrecho de Gibraltar y desde Sicilia al Golfo de Gascuña, pero sobre todo en la región aquitano-cantábrica (Dordoña, Lot, Pirineos, en Francia; Montes Cantábricos en España) (Huyghe, 1965, 41). Y hemos de excluir de la generalidad, asimismo, a las bandas creadoras del arte esquemático y levantino, que han proporcionado a la posteridad 
el conocimiento de un mundo simbólico, de un mundo de recolectores, cazadores, agricultores, de un mundo de guerreros.

Al respecto de las reiteradas afirmaciones hechas en párrafos anteriores acerca de que son angustiosamente escasas las figuraciones antropomoformas y zoomorfas o de cualquier otro tipo, y sobre cualquier soporte, sobre todo en las largas etapas del Bronce y del Hierro Antiguo, no llegaremos a saber la causa de por qué no tenían necesidad de imágenes no perecederas. Mas no por ello los dirigentes tribales o clánicos, no sólo de las zonas costeras del sur y suroeste, sino los dirigentes con hábitat en el interior, en la Meseta norte, en contacto con los mercaderes orientales, dejan de adquirir objetos suntuosos de metal, de madera con incrustaciones de marfil y metal, y/o tejidos, que no han perdurado integralmente, decorados con animales, con dioses, con hojas y flores, con motivos estilizados geométricos. $Y$ acerca de los diseños expresados, si bien han desaparecido de algunos de los soportes dichos, o incluso han desaparecido los soportes, sobre todo las telas, se ha conservado una pequeña fracción en pinturas post-cocción, sobre las superficies recubiertas con almagra, de ciertos vasos modelados a mano, datados entre los siglos VIII y VII a.C. Y finalmente cuando la cultura ibérica aparece ya plenamente formada, y obviando aquí los mecanismos de génesis, después del periodo de oscuridad documental en el que se sumerge la cultura tartésica, hay un reverdecer, para este escrito estrictamente de aquel fenómeno que denominamos su arte, que para ellos era más que nada el vehículo para expresar no conocidas pero intuidas ideas sociales y religiosas. Nos referimos exclusivamente a la escultura, y ya más tardíamente, y de manera muy efímera, a la pintura vascular. En cuanto a las civilizaciones celtas del Hierro II, éstas poseen, en la ideología religiosa que forja sus elementos artísticos, un potente aniconismo, por lo que se refiere a figuras antropomorfas y zoomorfas.

En un campo tan árido como el que hemos elegido, queda más que propuesto, como objeto de este corto estudio, la figura del ciervo, cuyo significado en las varias ideologías y culturas, para nuestro trabajo únicamente protohistóricas, es sujeto de numerosas interpretaciones, de las que cabe la posibilidad que ninguna se acerque excesivamente a la realidad. Su retrato majestuoso lo encontramos, en el transcurso de muy diversas periodizaciones, en diversos soportes y con diverso tratamiento - pintura vascular y parietal, grabado, toréutica, escultura en piedra- con carácter naturalista, geométrico, esquemático, con mejor o peor oficio.
Después de una corta incursión introductoria a sus figuraciones prehistóricas, y sobre el hábitat de este ungulado, apuntamos las dichas hipótesis acerca del por qué se encuentra el ciervo en la plástica, en diferentes periodos, y en diferentes lugares, tendiendo a tratar de demostrar, por lo que respecta al interrogante, que su presencia está relacionada con las creencias en relación con el Más Allá, pero no directamente, sino a través de un sinuoso ideario con multitud de bifurcaciones, en las que tiene mucho que ver la génesis de la fecundidad, el ciclo de la vida. El primer escollo escrito aparece, al respecto de esa hipotética relación con el Más Allá, ya en la Iberia romanizada, cuando hallamos al animal, como figura central, en un pasaje de ciertos autores grecolatinos, el único de que disponemos en estas fechas tempranas de la historia romana de la Península Ibérica: es el de la cierva de pelaje color blanco, utilizada por Q. Sertorio para embaucar a los lusitanos. Y en tal texto la misma no tiene, ni remotamente, relación con las ideas de ultratumba, aunque sí, probablemente, con la Diosa Madre, que directa o indirectamente (según los credos), está vinculada a la secuencia vida-muerte de la Naturaleza; argumentamos al respecto más abajo.

$Y$ antes de seguir permítasenos afirmar algo evidentemente obvio: existió, eso es indudable, un fin, tal vez espiritual, o menos, y siempre desconocido, para incluir en determinadas piezas muebles o superestructuras constructivas figuras de ciervos. Pues bien, ese acudir en lo que llamamos arte -que no era tal, ya lo proponemos arriba, para aquellos de cuyas manos salieron las magníficas obras que ahora admiramos y estudiamos-, específicamente al ciervo, con sentido más elevado que el de la materialidad, se inspiró, sencilla y elementalmente en su conversión -mediante una elaboración racional o irracional que se nos escapa- en animal totémico, en los orígenes más profundos del ideario que fuere, en el estadio más primitivo de los pueblos manejados. Y así, era un animal totémi$\mathrm{co}$, léase mejor sagrado, o si se quiere el animal simbólico de una deidad, pero nunca tuvo la calidad de divino ¿Por qué llegó a ser un animal vinculado con una deidad? porque lo conocían y admiraban todos aquellos que habitaban en el interior o en las cercanías de los bosque caducifolios, del matorral mediterráneo o de las laderas montañosas; porque era un animal bello, y por otro lado esquivo, pero a la vez cercano, por lo menos para los cazadores, que podían ser, en los parajes indicados, la mayoría de los hombres de las tribus de Iberia. 
Efectivamente, con él estaban en íntimo contacto: cuando avistaban entre el follaje la figura solemne y solitaria del ciervo macho, cuando oían en el silencio de la noche su voz profunda, la berrea, en la temporada de la brama (entre agosto y septiembre, según zonas), cuando lo hostigaban y cazaban. Después, la génesis de las diferentes potencialidades espirituales, de la calidad que fueren, del ciervo, el cuerpo clánico o tribal las va creando, se van complejizando, van evolucionando.

\section{EL BOSQUE}

La Península Ibérica estuvo cubierta por masas forestales que progresaron más y mejor al dulcificarse las condiciones climáticas ya hacia el Preboreal; estos sistemas forestales funcionaron durante miles de años prácticamente sin aporte externo, aparte de la energía solar y del agua. El bosque fue fuente de vida sin que hubiera que trabajar sobre él para modificarlo. El bosque constituyó un ambiente excepcional para los hombres de las civilizaciones que tratamos aquí, y para los de otras más viejas. Era, sin duda, un bosque denso, caducifolio, en el que los animales salvajes podían vivir libre y holgadamente: especies varias de grandes y medianos mamíferos, especies de mamíferos menores, aves, reptiles, anfibios, peces, insectos, etc., componiendo una biocenosis o agrupación natural de seres vivos animales y vegetales, completamente organizada. A la misma los humanos, en tiempos pretéritos, no la alteraron esencialmente, a pesar de que uno de los ungulados gregarios, habitante del bosque por excelencia, el ciervo, el verdadero monarca de los bosques, fue capturado masivamente en el transcurro de cientos y cientos de años, a más de otros diversos. Efectivamente, el ciervo es el taxón dominante en múltiples sedimentos arqueológicos prehistóricos. Y si se hubiesen analizado debidamente los residuos óseos de todos los poblados protohistóricos excavados, habría sido encontrada, con seguridad, su huella entre la fauna capturada y consumida.

La caza, en cuanto a la vida material, en cuanto a la obtención de alimento, supuso una parte considerable de la dieta, cuando aún la agricultura y la ganadería no se hallaban cumplidamente evolucionadas. $Y$ después, en tiempos posteriores, estando ya las dichas agricultura y ganadería definitivamente adaptadas y desarrolladas con destino al alimento de las poblaciones $y$, en su caso, a la producción de excedentes, siguió, como no, la tradición con respecto a la captura de los animales de bosque, para aporte de proteínas, además de servir a los componentes de las clases más favorecidas, de entrenamiento y demostración de sus valores físicos. $Y$ con toda probabilidad, según indicamos líneas atrás, las actividades cinegéticas de las partidas depredadoras de fauna mayor se centraron, por su cantidad, fundamentalmente en las manadas de ciervos ${ }^{1}$, menos en las de corzos (Capreolus capreolus), igualmente, como el ciervo, ligado al bosque. La captura del ciervo indicaría una actividad ejercida en biotopos forestales más o menos abiertos.

\section{EL CIERVO EN LA PREHISTORIA}

En el Paleolítico Superior ${ }^{2}$, en un crecido número de cuevas, sus habitantes, en parte de las paredes y techos, destinados a no ser vistos al entrar en la vivienda, dejaron constancia de grandiosas pinturas o grabados, éstos últimos solos o asociados con la pintura. Representan animales, aquéllos familiarizados con ellos, que dan testimonio de unas personas cuya facultad de observación se aproxima a la precisión ${ }^{3}$; a más de escasos seres humanos o partes del cuerpo -cabezas, manos-; y signos geométricos de muy difícil interpretación, como los denominados tecniformes, ramiformes, claviformes, esteliformes, escaleriformes, vulvas, puntos, rectángulos, cuadrados, etc. Y para ello hicieron uso de pigmentos elaborados con óxidos minerales (manganeso, para el negro; ocres, para el rojo y el amarillo), y materias vegetales, como el carbón, para el negro, mezclados con aglutinante orgánico, resinas; grasas o colas de origen animal, utilizando pincel, tam-

1. Las manadas pueden contar con varias decenas de ejemplares, hembras y sus crías. Aquéllas tienen estructura matriarcal y son dirigidas por una hembra adulta, por lo menos con una cría. Los ciervos machos o se mueven en solitario o viven en grupos reducidos, de alrededor de cinco individuos o menos. Se acercan a las hembras en época de celo.

2. Tanto la pintura como el grabado parietal o sobre guijarros o sobre huesos, aparecen desde el comienzo del Auriñaciense, aunque algunas de las representaciones, muy conseguidas, pudieran ser testimonio de experiencias artísticas anteriores. El arte rupestre paleolítico alcanza su plenitud en el Magdaleniense, y posteriormente, en el transcurso del Aziliense, se repliega.

3. El grado de naturalismo es, a menudo, profundo. E indudablemente los artistas hicieron gala de un conocimiento y análisis elevado de la anatomía de los animales y de la manera de desenvolverse en plena naturaleza, allí donde los veían. 


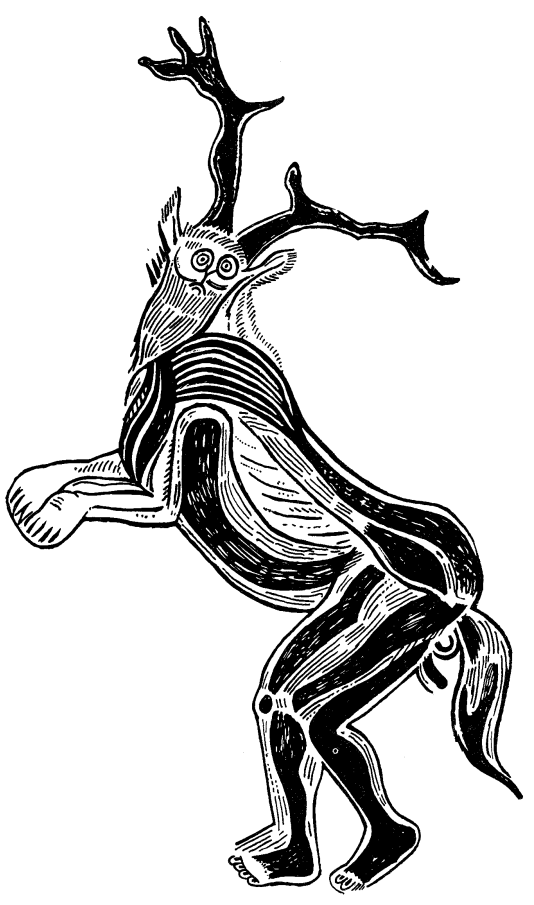

Figura 2: ¿Chamán? con piel de ciervo (según interpretación de H. Breuil). Cueva de Trois-Frères, en el Ariège (Foto Clark, 1973).

ponado o soplado. Son grafismos que, además de tener indudable valor artístico, contienen un altísimo interés para conocer las mentalidades de los hombres que vivieron en unos tiempos tan remotos, y que fueron capaces, en medio de la precariedad de una vida absolutamente dependiente de las fuerzas naturales, y tal vez por lo mismo, de representar la fauna que ellos conocían y de la que, en parte, dependían para subsistir. No fijaron, por el contrario, depredadores. Efectivamente, los animales son aquellos que los cazadores, que los pintores, avistaban en su medio ambiente, bisontes, caballos, ciervos, toros, cápridos, peces, menos renos y mamuts, aquí sólo atendemos a las imágenes de ciervos. Pero adviértase que en estas pinturas, en estos grabados, los animales no se representan generalmente realizando sus actividades más habituales o más dramáticas, como alimentándose, luchando, copulando. En términos coloquiales, si no los plasman en tales actitudes es porque no interesa a los propósitos de los que los reflejaron en las paredes de las grutas. Este aspecto está descartando que su fijación sobre el soporte, que ya es por sí un acto intelectual, por ejemplo, en el caso de la ausencia de apareamientos, tenga unos objetivos claros de generar fecundidad en los rebaños; y así sucesivamente iríamos eliminando fines, ¿entonces?

Idénticos motivos que en el arte parietal fueron ejecutados, mediante grabado, sobre un soporte mueble, previa preparación, para su transformación en el útil requerido, valiéndose de diversas herramientas líticas. Las materias primas utilizadas eran orgánicas -hueso, candil de cérvido, marfil (otras posibles perecederas han desaparecido)- o piedra. A veces los grabados eran rellenados con pintura, como un "bastón de mando" de la cueva del Castillo, Puente Viesgo, Cantabria.

El significado de este arte rupestre y mobiliar paleolítico - ¿lúdico, mágico, mítico, cohesionador de la identidad de la agrupación humana, etc.?- es uno de los problemas más interesantes para la investigación de los prehistoriadores, y una fuente de reflexión para todos aquellos que nos dedicamos al estudio de civilizaciones antiguas. Mas hay un aspecto absolutamente evidente, las pinturas están ahí para provecho de la comunidad, es decir de todos los habitantes de la cueva en cuestión, cuyo número no era alto, por ello los englobamos en una agrupación clánica, que en otros momentos denominamos grupo, no basándonos en precisiones concretas, entre otros aspectos porque no es este el tema específico del estudio.

La cronología, igualmente, es aún parte de un grave problema. Instrumentos válidos para datarlo son los utensilios decorados. Fechando los mismos, y manejando el sistema comparativo, puede llegar a alcanzarse la aproximación a la cronología del arte rupestre. Pero siempre y cuando las piezas muebles, en cuanto a sus representaciones, con un estilo similar al de las pinturas o grabados rupestres, hayan sido recuperadas en estratigrafía.

Los interrogantes expresados en líneas superiores son válidos, asimismo, para el arte rupestre esquemático y levantino.

Destacamos un reducido testimonio, en relación con la figuración de cérvidos, respecto a la pintura y grabado parietales, esos grandiosos monumentos del arte, reflejo, sin pormenorizar, de los movimientos mentales de aquellos seres:

En la cueva de Trois-Frères, en el Ariège, se halla una de las pocas figuras humanas existentes en el arte prehistórico, y en este caso cubierta con una piel de ciervo. Fue conocida a través de la interpretación que de ésta hizo $\mathrm{H}$. Breuil, aunque actualmente hay publicados otros calcos. Se trata del dibujo en negro de un enigmático e inquietante danzante, enmascarado, con gran cornamenta de ciervo ¿o reno?, barba, 
cola, parece que de caballo, y el sexo marcado (Fig. 2). Ha de ser o el hechicero o uno de los hechiceros o chamanes de la banda que habitaba en Trois Frères, es decir aquel o aquellos que tuvieron que ver con la religiosidad, entendiéndose por tal el mundo de ideas y creencias, muy abstruso, de los seres humanos que vivieron en la Prehistoria. El código simbólico implícito, en esta u otras ceremonias, en las que son necesarias las figuras de los chamanes, está normalmente constituido por una serie de rituales, con signos muy variados y complicados, a pesar del primitivismo de la cultura material. Éstos, a nuestro modo de ver, además de poseer otros beneficios, que desconocemos, pero que existieron, sirven para fortalecer los nexos sociales. Sigamos, como argumento hipotético el personaje podría ser un ojeador o un señuelo de la banda, y entonces mimetizado, teoría sin base alguna, demasiado simple. $Y$ rotundamente, una figura anecdótica carecería de valor en unas pinturas que tenían una fortísima carga mágica, definitivamente simbólica, definitivamente práctica, determinada hacia la existencia y bienestar colectivo del clan. A tal fin se llegaba discurriendo por unas vías actualmente insondables para nosotros, pero muy contundentes para quienes decidieron que había que integrar los murales en el ambiente de la cueva. $Y$ volviendo a Trois Frères, lo que es indudable es que entre las representaciones animalísticas hay una figura antropomorfa con astas, en una actitud aproximada de baile, siempre según $\mathrm{H}$. Breuil. En esta gruta hay otros dos seres híbridos (humanos, animales), grabados. Uno de ellos parece que tiene cabeza de bisonte y, en expresión de danza, con la pierna izquierda flexionada. Por la especie de caña que sujeta entre las manos, podría pensarse que está tocando un instrumento musical de viento. Se encuentra en medio de una cierta cantidad de animales de diferentes especies, en confuso desorden, algunos superpuestos (según calco del abate Breuil) ¿escenificación de la danza del animal? El segundo personaje tiene cabeza y cuerpo de bisonte y extremidades inferiores humanas.

El revestirse con pellejos de animales totémicos o asociados a dioses, para ceremonias diversas, religiosas o profanas, en fases críticas, de la vida y de la muerte, es un uso muy característico de los tiempos antiguos. No incidimos en ello, pero sí citamos, aunque se aparte enormemente del tema que tratamos en párrafos superiores, que tampoco es el asunto del trabajo, cómo cuando M. Claudio Marcelo sitió a los nertobrigenses, en el año 152 a.C., éstos le envia- ron un heraldo cubierto con piel de lobo (App., Iber. 48-49) ${ }^{4}$.

$Y$ tal vez existieron desviaciones hacia el terreno profano, transcurridos los siglos, de los bailes ceremoniales, protagonizados por hombres religiosos enmascarados y con la piel del animal de la máscara sobre los hombros; o desviaciones de la vestimenta de los hombres significados del grupo -no tenían que ser obligatoriamente los religiosos- que en alguna circunstancia precisa se revestían del poder de una divinidad, recubriéndose con el pellejo del animal sagrado del dios o de la diosa, al que requerían ayuda o protección, como el caso de los nertobrigenses. En otro orden de cosas pudiera ser que no existieran tales desviaciones, sino que las ceremonias civiles, acerca de las que tratamos más adelante, en las que gentes del pueblo se disfrazaban con pieles de animales, para nuestro caso con las de ciervo, tuvieran una génesis diferente, $y$ totalmente al margen de aquellas a las que aludimos arriba. Para una u otra cuestión, es patente, no hay elementos de juicio totalmente sólidos. Por lo menos no los conocemos, salvo los estudios de los antropólogos acerca de civilizaciones primitivas actuales, y el estudio de los comportamientos, de las formas culturales, de civilizaciones desaparecidas, de las que, según ellos y según nosotros, pervive algún que otro rasgo.

Siguiendo con la enumeración de cérvidos en el arte rupestre paleolítico, no debemos dejar de mencionar los de la cueva de Lascaux en Dordoña.

Las cuevas que se relacionan seguidamente son cántabras, en otro caso detallamos la situación:

Ciervos se encuentran en los murales de las paredes y techos de la cueva de Altamira, Santillana del Mar; en la gran sala central el grupo principal de bisontes está rodeado por otros diversos animales entre los que se halla una cierva; este ungulado, macho y hembra, igualmente fue pintado, en número escaso, en los pasillos de Altamira (Bernaldo de Quirós y Cabrera, 1982, 33,34). Ciervos se figuraron en la cueva de Covalanas, en las inmediaciones de Ramales de la Victoria y cercana a la cueva del

4. El dios celta Sucellus aparece en alguna que otra figuración con la cabeza y hombros cubiertos con piel de lobo. No obstante, sea Sucellos o cualquier otra deidad del panteón propio, el concepto del heraldo nertobrigense estribaba en revestirse, ante el enemigo, de la sacralidad y protección que emanaba de aquel, para nosotros desconocido, dios o diosa vinculado a los lobos o éstos vinculados al dios. 


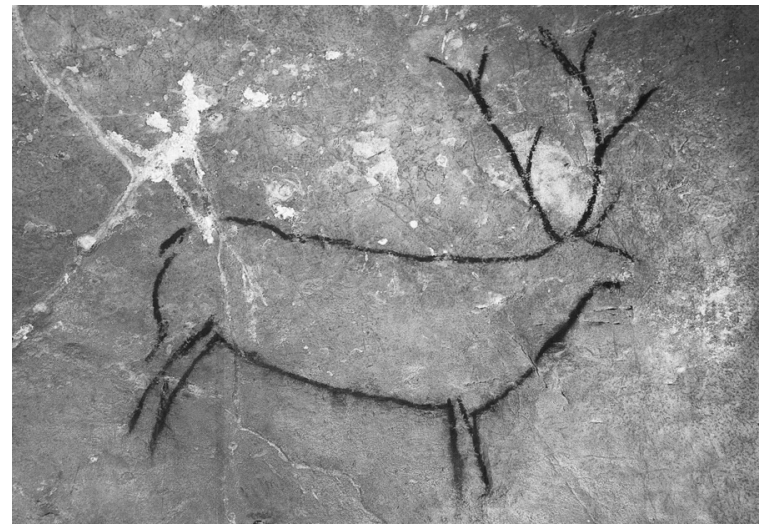

Figura 3: Ciervo de la cueva de Las Chimeneas, Puente Viesgo, Cantabria (Foto Rev. Arqueología, 1987).

Mirón, ésta actualmente en proceso de investigación. En las dos paredes de la galería derecha, aproximadamente a $75 \mathrm{~m}$. del acceso principal, se encuentra el mayor y mejor elenco de ciervas existentes en la pintura rupestre paleolítica, alrededor de dieciocho ejemplares, en actitudes diversas, que constituyen, con excepción de un caballo y un probable bóvido, la única especie animal representada (Bernaldo de Quirós y Cabrera, 1982, 22). En la cueva de Chufín, cerca de Rábago y Celis, hay ciervas grabadas (Bernaldo de Quirós y Cabrera, 1982, 35). En la cueva del Castillo hallamos, casi a la entrada un conjunto de cabezas de cierva grabadas y más adelante dos ciervas pintadas con pigmento rojo; siguiendo el itinerario de la cueva vuelven a hallarse dos ciervas grabadas (Bernaldo de Quirós y Cabrera, $1982,25,26)$. Las pinturas y grabados de la cueva de Las Chimeneas, Puente Viesgo, están integradas, en cuanto a fauna, por el ciervo, en un porcentaje del 40,6 \% (Fig. 3) En Asturias, en la cueva del Pindal, cerca de Pimiango, en el panel central, hay figuras de ciervos grabados y pintados, además de otros animales, y de entre los ciervos destaca uno de gran prestancia, junto a un bisonte (Bernaldo de Quirós y Cabrera, 1982, 38). En el panel central de la cámara principal de la cueva de Candamo, en San Román, igualmente en Asturias, hay grabados dos espléndidos ciervos heridos (Bernaldo de Quirós y Cabrera, 1982, 46).

En el arte rupestre esquemático y levantino, asimismo, se utilizó la pintura y el grabado, éste escaso. $Y$ predominan en la pintura las tintas planas, siendo los pigmentos más empleados el rojo, el negro y el blanco, de igual procedencia y con similar aglutinante que los de los referidos murales septentrionales. Si no especificamos otra cosa, se trata de pinturas. Se carac- terizan por crear escenas de alto dinamismo y expresividad, siendo las figuras humanas menos naturalistas que las animales. Éstas se encuentran, bien en solitario bien en grupos, inmóviles o en movimiento, asociadas o no a las circunstancias diversas en las que participan hombres y mujeres. E igualmente se representó el ciervo (además de cabras salvajes, toros, jabalíes, menos corzos, caballos, gamuzas), como lo que en esencia fue, uno de los animales más interesantes de captura. Y parece ser un canon el que todos posean impresionantes cuernas, como el detalle anatómico a resaltar:

En la cueva del Tajo de las Figuras, en Benalup-Casas Viejas, Cádiz, entre un número considerable de representaciones de aves, antropomorfos y cuadrúpedos, hasta en lances de caza, se encuentran ciervos, determinados mediante trazos simplificados, geométricos. Igualmente, ciervos se hallan en la cueva de Bacinete, Los Barrios, Cádiz. Ciervos hay en la de Los Cantos de la Visera, Monte Arabí, Yecla, Murcia. En la provincia de Valencia, zona de Bicorp, en el abrigo del Charco de la Madera, hay escenas de caza de cérvidos; en el abrigo de la cueva de La Araña, junto a una cabra montés, se dibujó un ciervo y una cierva; en Millares, en el abrigo de Vicent aparecen un ejemplar de cérvido y un episodio de caza, en el que seis arqueros acosan a

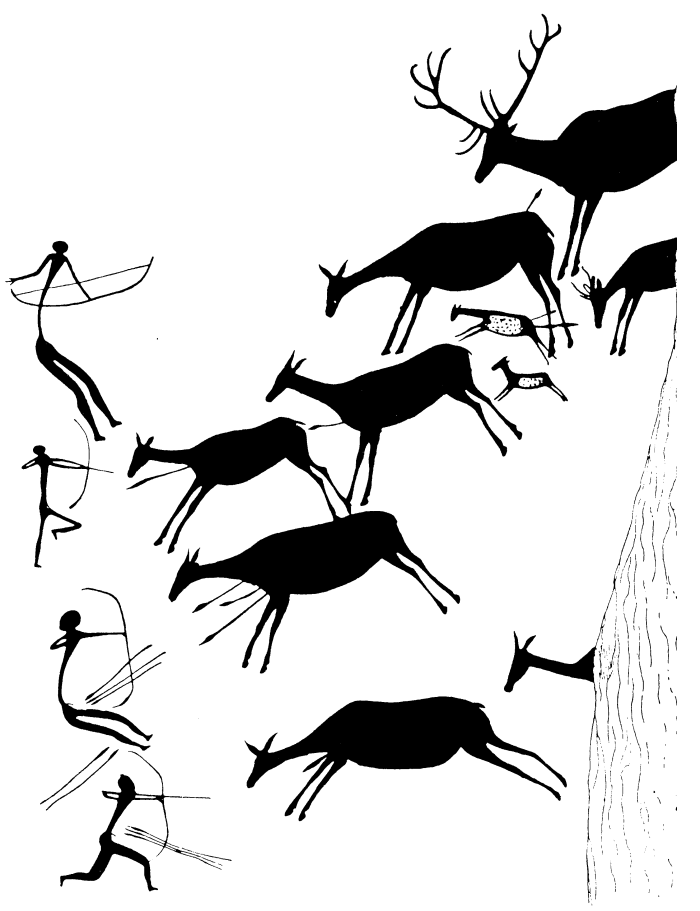

Figura 4: Calco realizado por $\mathrm{H}$. Breuil y $\mathrm{H}$. Obermaier de un panel pintado en el Barranco de Valltorta, Castellón (Foto Hernández Pérez, 1987). 


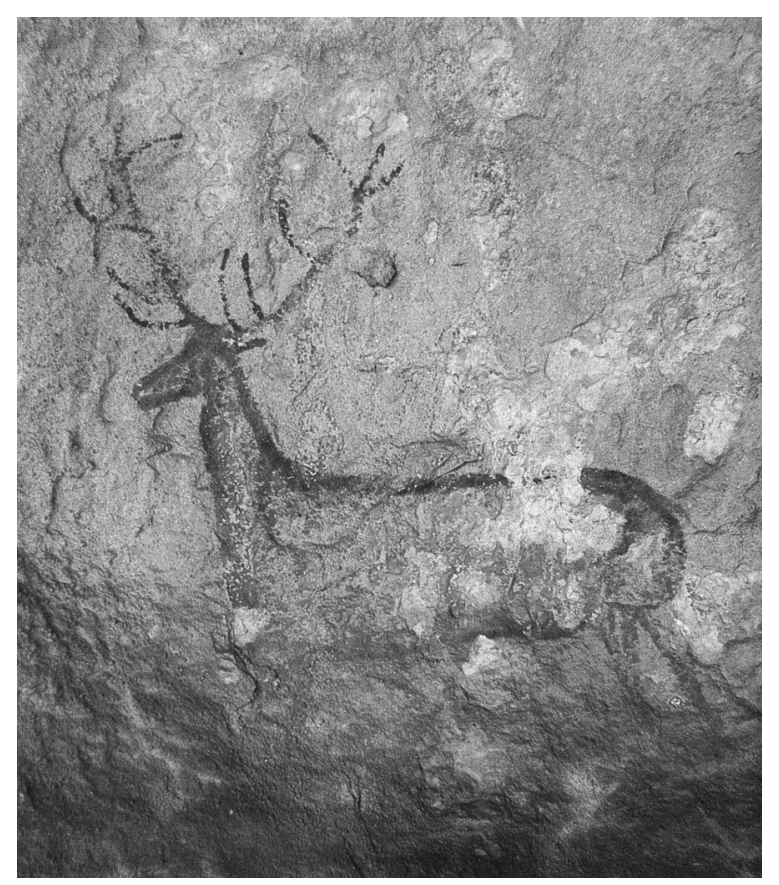

Figura 5: Ciervo de Chimiachas en el Parque Cultural del Río Vero, Huesca (Foto Baldellou, 1987).

un ciervo con una aparatosa cornamenta; en el mismo territorio de Millares, en el abrigo de Las Cañas, a más de cabras y un bóvido, hay ciervos; en Enguera, en el abrigo del Charco de la Pregunta, está figurado un ciervo y un arquero; en Mogente, en el abrigo de La Penya, un cazador vigila a un ciervo y a una cierva. En el barranco de Valltorta, Castellón, está representada, con realismo y dinamismo, una cacería de ciervos (Fig. 4). En Alcoy, Alicante, en el abrigo de La Sarga, hay figuras de ciervos entre otras zoomorfas. En las pinturas de Cogul, comarca de Les Garrigues, Lérida, se disponen seres humanos y diferentes especies de animales, entre ellas cérvidos. Éstos se encuentran en las pinturas rupestres de Huesca, en cavidades del Parque Cultural del Río Vero, situado entre el Prepirineo y el Somontano de Barbastro, cuales son los magníficos ejemplares de Chimiachas (Fig. 5), de Arpán, y la escena de caza de Muriecho, en la que se captura a un ciervo vivo. En Teruel, en el término de Albarracín, hay ciervos grabados, como en Fuente del $\mathrm{Ca}$ brerizo; siguiendo en el mismo término turolense se encuentra el conjunto de pinturas del Prado de las Olivanas, Tormón, con figuras humanas, de ciervos y de bóvidos esquematizadas.

Y como último ejemplo de la utilización del ciervo en la plástica rupestre, entre los innumerables que pueden manejarse, he ahí los grabados al aire libre, localizados en amplias zonas de Galicia (Fig. 6), cuya cronología, es difícil de verifi- car, aunque en general deben datarse desde el megalitismo hasta la fase de la cultura castreña correspondiente a la Edad del Hierro (Vázquez Varela, 1987, 110).

$Y$ de entre los huesos, candiles, o guijarros adecuados, grabados con figuras de ciervos, machos o hembras, destacamos una breve selección que, salvo que se indique otra localización, proviene de cuevas de Cantabria. Se hallan representados con finas líneas o trazos profundos de buril, esta herramienta generalmente sobre sílex y, a pesar de la economía del signo gráfico, con expresiva visión naturalista, algunos más que otros, al respecto de la anatomía, del movimiento:

"Bastón de mando" sobre asta de ciervo de la cueva del Valle, Rasines, cuyo tema principal, empleando incisión, es una gran cabeza de cierva de perfil, constituía por breves y precisos trazos, estando cubierta de puntos y cortas líneas (García-Gelabert et al., 2004,56-58, 255; GarcíaGelabert, 2005, 115-116, con toda la bibliografía). Fue hallado fuera de contexto sedimentológico, en 1912, por L. Sierra, y en la actualidad está en paradero desconocido, existiendo en el Museo Arqueológico Nacional de Madrid un molde, que no recrea totalmente el original. De la misma cueva, e igualmente sin localización precisa en estratigrafía, fue recuperado, en 1911, por $\mathrm{H}$. Obermaier, un radio de ave, en el que además de dos soberbios caballos, en marcha hacia la derecha, hay una figura de ciervo esquemático, trazos oblongos rellenos de líneas y ciertos signos, actualmente sin identificación posible (García-Gelabert et al., 2004, 63; García-Gelabert, 2005,115 , con toda la bibliografía). "Bastón de mando" hallado en la cueva del Pendo, Esco-

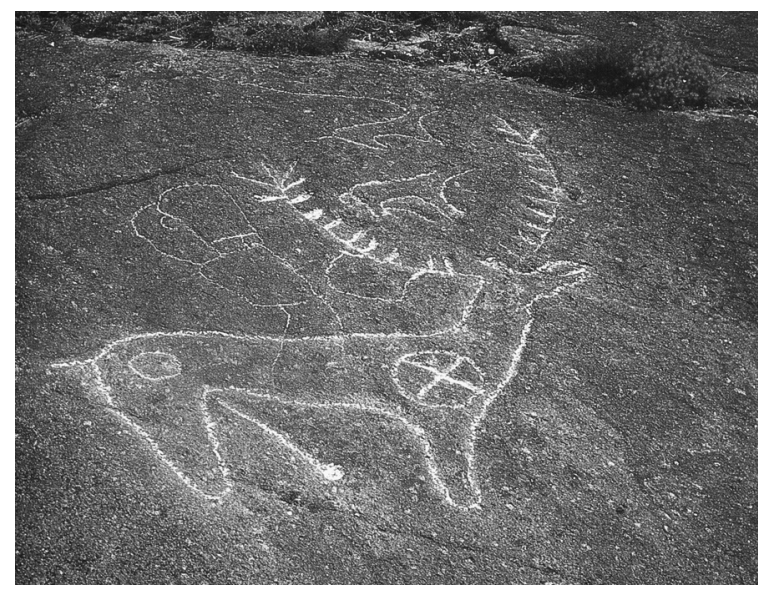

Figura 6: Ciervo de Campo Lameiro, Pontevedra (Foto Vázquez Varela, 1987). 
bedo de Camargo, sobre asta de ciervo, en el que hay grabadas, con finísimo trazo, y riqueza expresiva, tres cabezas de cierva, una de ciervo y una de caballo. "Bastón de mando" tallado sobre candil de ciervo de la cueva del Castillo. Mediante fuertes trazos, un ciervo, con grandes defensas, ocupa la mayor parte de la superficie, adaptándose al marco.En un omoplato hallado en la cueva de Altamira, destaca una cabeza de cierva, cuyo estilo es semejante al de las pinturas de las paredes. En un hueso de Lortet, Altos Pirineos, un gran ciervo con la cabeza vuelta en un abrupto escorzo, forma parte de un grupo de varios congéneres, muy perdidos, además de varios peces.

\section{EL CIERVO EN LA TORÉUTICA ORIENTALI- ZANTE DE LA EDAD DEL BRONCE FINAL}

Como escribía A. Blanco, el Bronce Final es un periodo sin esculturas, pero el ciervo está reiteradamente representado en objetos de culto diversos, que se utilizaron en rituales en la tierra, sí, pero que, como ajuar, terminaron sirviendo a aquél o aquéllos que habían emprendido su marcha hacia el Más Allá.

En la Edad Final del Bronce el carácter funerario del ciervo, entre las poblaciones del cuadrante suroccidental andaluz y sur de Extremadura y Portugal parece, de forma relativa, estar atestiguado. Es así en cuanto a que especulamos al respecto de algunos bronces, cabe suponer que importados de Fenicia, los cuales tuvieron, verosímilmente: primero la particularidad de ser encargos gestionados por los señores preclaros, con referencia al motivo nuclear, que es el ciervo, porque no forman parte del repertorio característico que adorna estos bronces orientales. Las gestiones se efectuarían a través de comerciantes, agentes $\mathrm{o}$ artesanos tirios. $\mathrm{O}$ de igual forma pudo ser que éstos, sabedores de las preferencias de los jefes peninsulares, hicieron que fueran producidas las decoraciones tal como ellos deseaban, es decir, con los motivos adecuados a sus convicciones, para darles mayor satisfacción ${ }^{5}$. Y, segundo, que una parte

5. Los dirigentes o aquellos a los que competía tratar, por delegación, con los artesanos o comerciantes fenicios se basaban, como es evidente, para dictar las normas de composición de las figuras de la toréutica, en aquéllas que pudieran poseer que, porque no se han hallado, debían estar talladas sobre madera $\mathrm{u}$ otro material perecedero. $\mathrm{O}$ bien aceptaban los esquemas, según su dictado, hechos por los artesanos o intermediarios. de estos bronces se han encontrado, a menudo, entre los ajuares de los sepulcros (otros fuera de contexto, fundamentalmente en Extremadura). Por otro lado entraría dentro de lo posible, y precisamente por la aplicación de sus efigies en lugares tan sagrados y honrados como lo fueron para los hombres de la Antigüedad las tumbas, que el ciervo fuera adorado, o más bien le fuera atribuido una cierta categoría divina no por sí mismo, no por ser considerado un dios, sino por ser el animal vinculado con una deidad propia, venerada desde los tiempos primordiales. Divinidad para nosotros desconocida, pero sí, en conexión con la fertilidad de seres y humanos y animales ¿por qué no un dios o la diosa madre de la muerte y de la vida que hallamos, sin excepción, en la raíz de todas las religiones? Por cierto, siempre escribimos acerca de una Diosa Madre, en otros artículos acerca de la Gran Diosa, es una manera personal (García-Gelabert) de denominarla aún para la Protohistoria, aunque tiende a no ser usual. Pero los apelativos de aquellos dioses, que no sabemos cómo eran nombrados por los que los adoraban es, al fin y al cabo, lo menos substancial, lo que importa es tratar de llegar, por lo menos, a un sumario conocimiento, y es incluso una idea muy ambiciosa, de aquellas ignotas realidades religiosas, recorriendo los senderos que fueren necesarios. Escribimos acerca de una diosa primordial y suprema, sin menoscabo de los numerosos dioses que abarca un panteón politeísta, como habría de ser el de los hombres de Iberia, de épocas arcaicas y menos. Y los autores sienten una curiosidad, en cierto modo superficial, al respecto de cual sería su nombre entre las muy diversas tribus peninsulares. Sigamos con el ciervo, ¿cuál es la causa de esta hipotética vinculación con la deidad que fuere para dicho animal de bosque? ¿Cuál es el desarrollo mental religioso que lo convirtió en tal y cuándo? Son interrogantes que no ha lugar a contestar con el escaso patrimonio documental que poseemos, pero ahí está. Por otro lado, si tomamos como un argumento a favor del carácter funerario el hecho, único y exclusivo, de hallarse formando parte de una tumba, bien, si, lo tiene. Pero si tal hecho no es absolutamente determinante de su condición, excluyendo cualquier otra, $-y$ no creemos en una exclusividad del ciervo para la muerte-, debe aducirse, entonces, que pudiendo ser considerado, como indicamos arriba, el animal simbólico o sagrado de una divinidad patrimonio espiritual de los peninsulares, y más si lo fue de un dios y más si lo fue de la Diosa Madre, tendría sentido su presencia en las tumbas, bien como animal protec- 


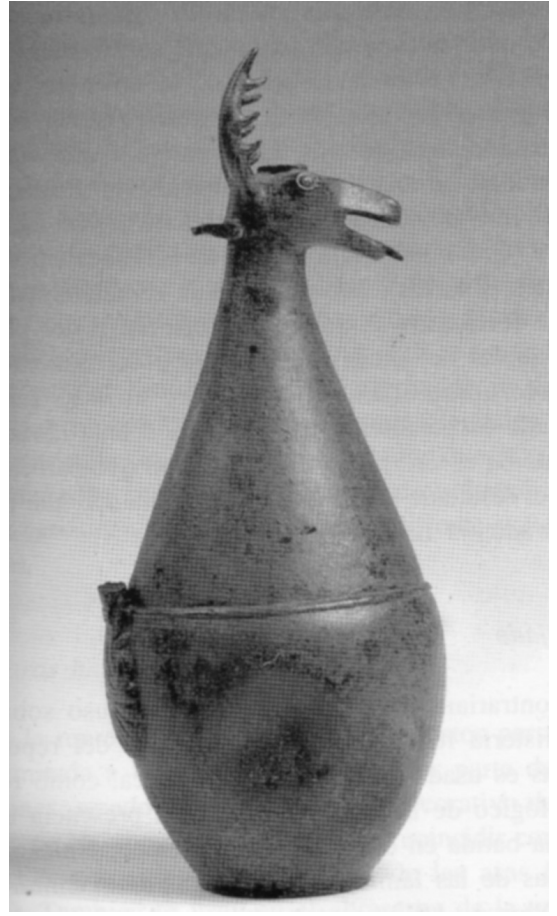

Figura 7: Jarro de La Zarza, Badajoz (Foto Novillos, en Jiménez Ávila, 2002).

tor, bienhechor, mediador, bien como animal que aporta esperanza de pervivencia más allá de la muerte. En este último caso si es que el ciervo, es una de las muchas hipótesis que cabe barajar,

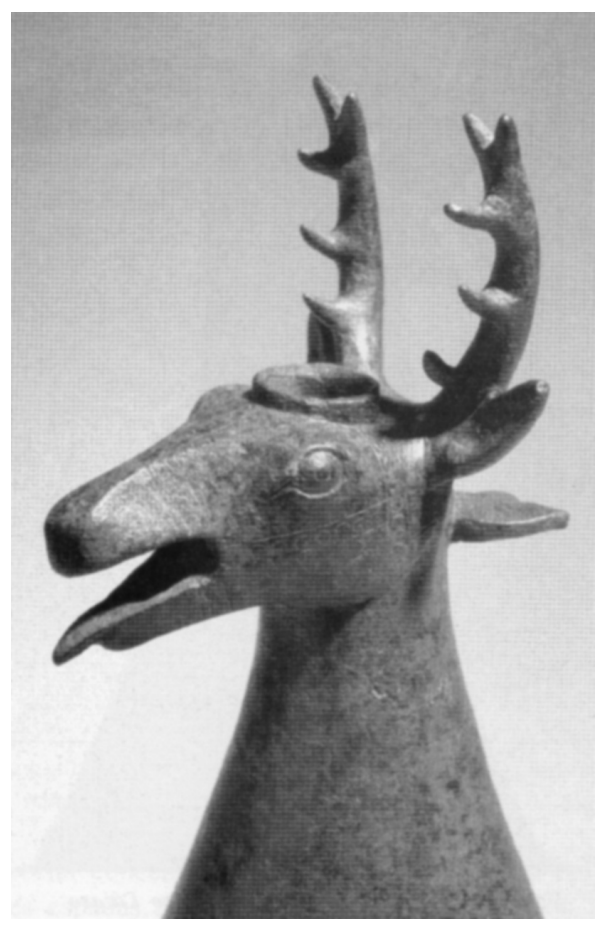

Figura 8: Boca del jarro de La Zarza, Badajoz. Obsérvese la cabezada incisa (Foto Novillos, en Jiménez Ávila, 2002). fuera conceptuado como uno de los animales fecundantes, o el único, de la divinidad que da vida a seres animales y vegetales ${ }^{6}$.

Y así, la presencia de los bronces con figuras de ciervos en las tumbas, tendría varias interpretaciones, 1. La propia aplicación del bronce en cuestión. 2. La aplicación apotropaica y/o de esperanza del ciervo sagrado del dios o de la diosa en la tumba, amén de, por lógica, 3. La disposición en vida, de la persona fallecida, acerca de la composición de su ajuar, en el que los objetos adornados con ciervos, conforme a los apartados 1 y 2 , eran considerados entre los esenciales en el mismo y, tal vez, 4. La más íntima, merced a la cual, la amortización en el ajuar mortuorio de objetos con valor sagrado en la vida terrenal, implica, sin más, y es suficiente, el afecto familiar o amistoso hacia la persona fallecida, para que goce de los beneficios aplicables a los objetos que le acompañan al Más Allá.

\section{a) Jarros}

Los jarros de bronce es muy probable que estén relacionados con libaciones o abluciones, y en asociación con otros recipientes asimismo de bronce, que comúnmente son denominados "braserillos". Son dos, los conocidos, que ostentan figuras de ciervos en su anatomía. He ahí:

6. Es aproximadamente el mismo sentido simbólico, si es que fue así, que tuvo el toro, aunque el de éste estuvo considerablemente más marcado y extendido, tanto en el espacio como en el tiempo, en el Próximo Oriente y, por extensión, en todo el Mediterráneo, a partir de la oikouméne orientalizante, y aún antes. $Y$ concretamente en las tumbas iberas de alto estatus, hay más esculturas de toros que de ciervos. Véase la gran cantidad de toros que se encuentra en la necrópolis contestana de Cabezo Lucero, Guardamar del Segura, Alicante (Aranegui, Jodin, Llobregat, Rouillard y Uroz, 1993, 73-85). En cambio el toro en el área indoeuropea, siempre teniendo presente su aniconismo específico, no fue un animal que gozó de gran aceptación en su universo religioso, aunque aparece en algunas escenas sobre estelas funerarias tardías, no desde luego, como entre los pueblos iberos.Y al respecto del ciervo hay una nota interesante, que a juicio de uno de nosotros (GarcíaGelabert) lo aleja, en cierto modo, aquí de la espiritualidad: los componentes de los grupos de etnia indoeuropea peninsulares, sí parece, por la información que aportan las estelas, que conceptúan al ciervo como animal que debe y puede ser figurado en las mismas, no porque lo consideren protector de los difuntos, sino porque sencillamente plasman en las dichas a fauna domestica o de monte, proclive ésta a ser capturada y, por tanto, ¿cómo no iba a figurar en ellas el ciervo si debía ser uno de sus objetivos cinegéticos favoritos? Sobre ello argumentamos en texto principal. 
- Jarro fenicio-oriental de La Zarza, Badajoz, fechado, según J. Jiménez Ávila (2002, 93), en el siglo VII a.C. (Figs. 7, 8 y 9). Perteneció a la Colección Calzadilla, cuyo propietario lo adquirió a unos labradores en las cercanías de La Zarza, en abril de 1957, luego carece de contexto arqueológico preciso. Fue estudiado, pocos días después del hallazgo, sin apenas estar limpio aún, por A. García y Bellido (1957, 121-123, figs.1-9). Posteriormente lo manejaron, en sus trabajos, otros investigadores, al igual que los restantes objetos determinados aquí, por lo que no repetimos esta circunstancia ${ }^{7}$; y fue restaurado, apreciándose, entonces, detalles que, en principio, habían pasado desapercibidos, como el hecho de estar provisto el ciervo de una perfecta cabezada, cual si se tratara de un équido domesticado. Últimamente, J. Jiménez Ávila (2002, 93, 102, 343, 388, fig. 74, láms. VII, VIII) lo incluyó en su magnifico estudio de la toréutica orientalizante. Su forma general es piriforme. El cuello del recipiente sostiene una cabeza de ciervo de bulto redondo, que tiene la boca entreabierta con la lengua fuera sobre el belfo inferior. En la zona alta de la cabeza lleva un orificio para introducir el líquido que era vertido, después, por las fauces. Los ojos y el lacrimal están señalados, son grandes y con las pupilas indicadas. Las orejas son igualmente amplias y empinadas. Junto a ellas arrancan, hacia arriba, las cuernas, de cuatro puntas, perfectamente conservadas. Acerca del correaje de la cabeza del ciervo, escribe J. Jiménez Ávila $(2002,102)$, con el que estamos de acuerdo, que un ciervo no puede ser domesticado fácilmente. Y, por tanto, emplearlo como transporte de hombres o de mercancías o en las labores agrícolas, es impensable. Suele ocurrirles a estos animales que viven en la naturaleza, que si son sometidos a un trauma fuerte, como la captura y después el intento de doma, sufren un paro cardiaco, que les produce la muerte. Cualquier animal en libertad puede morir al ser reducido a prisión, véase, son escasísimos los pequeños pájaros silvestres, jilgueros, gorriones, alondras, verderones, los que más usualmente son apresados en nuestros campos, para diversión de unos bárbaros, que consiguen sobrevivir, dejando de existir en breves días, a veces en horas. Volviendo a la imposibilidad de domar a los ciervos, en otro apartado de este estudio exponemos el texto relativo a la cierva blanca de Q. Sertorio. Ahí está el ejemplo de un animal de bosque que vive con los hombres, en el supuesto

7. Cf., entre otros, Jordá y Blázquez, 1988, 213. de que el suceso sea real, que pudo serlo. Pero aquí hay un fondo completamente diferente. Si los animales son apresados en edad muy temprana, la cervatilla del militar romano lo fue sin estar destetada, hay más posibilidades de que sobrevivan y sean fieles a la persona o personas que los cuidan y/o que los rodean de agasajo. Siguiendo con el jarro de La Zarza, J. Jiménez Ávila $(2002,102)$ continúa argumentado sobre el ciervo embridado "es posible que esté representando un mito o relato alusivo a la unión de un ciervo y un caballo... La inexistencia de nada semejante en la mitología oriental que nos ha sido transmitida anima a incorporar esta escena al corpus de leyendas y creencias propias de la Península Ibérica. La abundancia de ciervos en la toréutica orientalizante peninsular puede contribuir a verificar esta hipotética lectura, pero el aniconismo atávico del Bronce Final hispánico (al que nos referimos en otros lugares) y la falta de textos constituyen trabas importantes de cara a su confirmación".

En las culturas peninsulares hay una sentida ausencia de la historia escrita propia, por ello los mitos, que sin duda, existieron en el patrimonio espiritual de todos y cada uno de los grupos humanos autóctonos, a través de los tiempos, se han perdido, al desaparecer la transmisión oral, porque obviamente desaparecieron los sujetos activos. Quedan, no obstante, ciertos ecos, reflejados en textos griegos, quedan ecos reflejados en la plástica, como son, tal vez, los insólitos ciervos y caballos, en extraña unión, de los jarros de La Zarza y de la necrópolis de La Joya, Huelva (Fig. 9). Y algunas escenas de la pintura de los vasos tardíos introducen al que las contempla en un círculo ideológico abundante en asuntos metafóricos y matices extraños; en un círculo confuso; en un universo de monstruos y seres sobrehumanos, de mitos, tal vez relacionados con el origen del hombre. En esta última categoría, en cuanto a contenido, estaría catalogado el expresado en una tinaja, recuperada en el nivel de destrucción de Valentia, durante las actividades bélicas de Cn. Pompeyo el Magno del año 75 a.C., contra los partidarios de Q. Sertorio; aunque es una pintura de la época de disolución, material, de la cultura ibérica, por la conquista y aculturación romana, la religión propia siempre es eminentemente conservadora ante las agresiones, implícitas, de otras culturas; por ello este probable mito puede situarse en la raíz de los mitos esenciales ibéricos. Otra escena nebulosa, simbólica, imposible de interpretar, como la anterior, es la de un vaso de Los Villares de Caudete de las Fuentes, Valencia, con seres fantásticos, animales híbridos, y 
hombres yaciendo bajo monstruos. El vaso debe datarse entre los siglos II y I a.C.

Un mito muy conocido, el de Habis, en el que tiene un cierto protagonismo una cierva nutricia, según J . Bermejo $(1982,85)$ "pertenece al complejo cultural tartésico", aunque, desde luego, en cuanto a la estructura y a gran parte del texto, es de procedencia griega. Concretamente, la cierva de la narración incorpora a su manada y mantiene a un pequeño ser humano abandonado, Habis, generando vida en él. Esa vida que intentó arrebatar, tras múltiples intentos fallidos, el rey de los cunetes, Gárgoris. Acerca de la figura del ungulado hay varias posibilidades: ¿Una concesión a la biomasa de la región en que se desarrolla el mito? ¿La diosa o dios protector del que después será rey, Habis, envía a su animal totémico para conservarle la vida y fortalecerlo? En los mitos relacionados con ciertos personajes insignes, abandonados inmediatamente después del nacimiento, siempre hay un ser elevado salvador, un dios o una diosa, que se vale, en ciertos casos de un animal a él asociado, o de un ser humano sencillo. Uno de los arquetipos más cercanos es el de los gemelos Rómulo y Remo, hijos de Rea Silvia y de Marte, a los que amamantó la loba Luperca, vinculada con el dios, hasta que el pastor Fausto se hizo cargo de ellos. El mito de Habis fue transmitido por Justino (Epit.Hist.Phil. XLIV, 4,1), quien lo recogió de Trogo Pompeyo, historiador de tiempos de Augusto, el cual, a su vez, se inspiró, con toda probabilidad, en autores más antiguos, cuyos nombres entran en el campo de la hipótesis, como, entre otros, Posidonio y Asclepiades.

En el mito, Habis fue vástago incestuoso del rey Gárgoris y de una de sus hijas. El monarca ordenó deshacerse de él en el monte, donde las fieras lo amamantaron. Ante ello lo colocaron en un desfiladero por el que pasaban los rebaños, pero éstos lo evitaron. Después lo dieron a unos perros y cerdos hambrientos, que lo respetaron. Finalmente lo arrojaron al mar y el mar lo devolvió. Y en la orilla una cierva lo amamantó: “...poco después acudió allí una cierva que amamantó al niño. A partir de entonces, gracias al contacto con su nodriza, el niño adquirió agilidad; en medio de las manadas de ciervos recorría los montes y los bosques con una velocidad similar a la de ellos. Finalmente, apresado con lazo por unos cazadores, fue enviado como regalo al rey, su padre y abuelo...". El colofón al destino del niño, ya es sabido, el rey, maravillado, lo nombró heredero. $\mathrm{Y}$ se convirtió en un héroe civilizador: “... Incluso sometió al pueblo bárbaro con las leyes y fue el primero en enseñar a arar la tierra
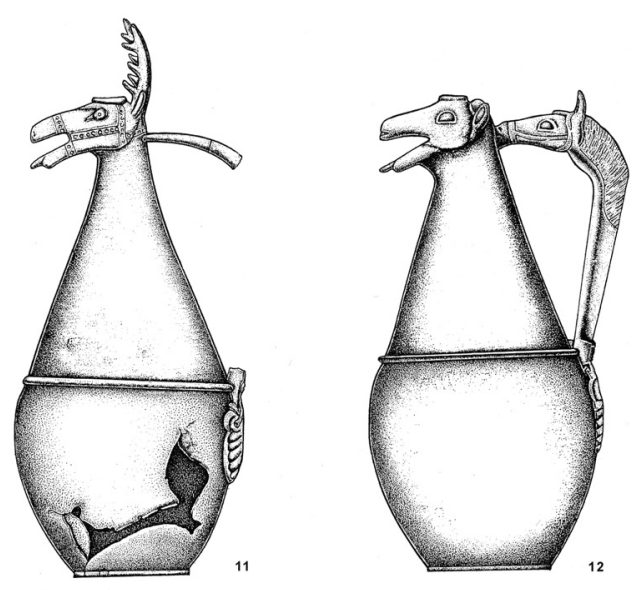

Figura 9: Jarros de La Zarza, Badajoz y de la necrópolis de La Joya, Huelva (Dibujo Jiménez Ávila, 2002).

con bueyes y a cultivarla; además, obligó a los hombres a alimentarse con alimentos del campo por odio a todo aquello que él mismo había padecido...Prohibió a los nobles los oficios serviles, $y$ dividió a la plebe en siete ciudades..."

- Un segundo jarro piriforme, de bronce, es el hallado entre el ajuar de la tumba 18, de la necrópolis orientalizante de La Joya (Jordá y Blázquez, 1988, 214, fig. 9) (Fig. 9). La tumba estaba compuesta por dos pozos, A y B. En el B se hallaron vestigios de cremación y de inhumación. Contenía un valioso ajuar, entre los objetos más destacados, restos de un carro y un "braserillo" de bronce, que se complementaría, en cuanto a funcionalidad, con el jarro. Sus investigadores, en un párrafo, fijan la vida de esta necrópolis desde fines del siglo VII hasta la segunda mitad del siglo VI a.C. (Garrido y Orta, 1978, 200), y un poco más adelante exponen que "... no obstante para el área de hábitat próximo poseemos elementos que nos retrotraen al siglo VIII a.C. o quizás antes" (Garrido y Orta, 1978, 210). El jarro de La Joya ofrece la particularidad notable de la unión de un ciervo y un caballo, lo que implica la plasmación, tal vez, del posible mito desconocido patrimonio de ciertas agrupaciones tribales de la Península Ibérica, al que hace mención $\mathrm{J}$. Jiménez Ávila $(2002,102)$, según datos expuestos más arriba, en el que se da la simbiosis entre caballo domesticado y ciervo. En realidad en el jarro de La Joya ocurre lo mismo que en el jarro de La Zarza, en el cual no hay caballo, pero sí hay uno de sus aditamentos, aplicado al ciervo, el correaje que ciñe la cabeza. Y en cuanto a la lectura de los mismos, en cuanto que representen un mito autóctono, bien, hay un abanico de posi- 
bilidades, puede ser, pero lo que no es factible, bajo ningún concepto, es saber concretamente el contenido del mito representado. Retomando el jarro de La Joya, la cabeza de ciervo, sin cornamenta -ésta se perdió o no se fundió- decora la boca del jarro, como en el ejemplar de La Zarza; y como éste, y como una gran parte de las representaciones de cérvidos en la estética orientalizante, lleva la boca entreabierta, y la lengua, larga, al exterior, sobre el belfo inferior; las orejas son del mismo modo largas y empinadas, igual las del caballo referido líneas abajo; los ojos, semicirculares son semejantes a los del équido. La extremidad superior del asa es un prótomo de caballo, cuyo hocico ensambla con la nuca del ciervo, la inferior es una palmeta. El caballo lleva una completa cabezada, y la crin bien marcada.

\section{b) Thymiateria}

Estos artefactos, decorados con cérvidos y con otros motivos diversos, se encuentran en necrópolis del sur o del interior, en más de un enterramiento cargado del ambiente orientalizante del Bronce Final, en cuanto a su ajuar, y nunca se han hallado en sepulcros posteriores, es decir, de la fase ibérica. Y se localizan en tumbas, quizá en razón de que los amortizaron, como lo hicieron con los jarros, "braserillos" (recipientes para recibir el líquido de los jarros, probablemente en función de libaciones $u$ otros actos relacionados con los dichos líquidos, cuya calidad, ciertamente, desconocemos), y otros objetos. El depositarlos en las tumbas, después de haberse usado en las ceremonias funerales, conlleva una simbología que desconocemos; o bien se amortizaron, conforme a lo expuesto en los apartados 2), 3), 4), situados en los párrafos introductorios de este bloque relativo a la toréutica orientalizante. $Y$ si se conservaron de los ladrones en alguna que otra tumba, hasta ser excavadas, no ocurrió lo mismo con aquellos thymiateria que siguieron utilizándose para rituales diversos en la tierra: por múltiples circunstancias, situación bélica, desaparición de los habitantes de un lugar, u otros casos, y por ser objetos de metal, muy pronto se apoderan de ellos, quien quiera que fuese, y desaparecen, vendidos, fundidos, etc.

El pueblo llano si bien no tenía poder adquisitivo para adquirir los impresionantes thymiateria importados, sí tenía las mismas creencias; e indiscutiblemente si les era necesario a los más favorecidos socialmente producir humo oloroso en los rituales, a los menos favorecidos socialmente ¿por qué no les iba a ser necesario igualmente? ; así pues éstos utilizarían recipientes de arcilla, de madera o de otros vegetales, pertinentes a las circunstancias, no localizados muy concretamente en excavación.

En las regiones indoeuropeas hispanas no se hallan thymiateria, siempre las relaciones con los comerciantes fenicios fueron mínimas. Y, en el caso de la llegada de algún enser manufacturado en los talleres de Tiro, que constan en registro arqueológico, destinado a las clases privilegiadas, se trataba, en cuanto a materiales perennes, de otros efectos, cuales son : los bronces del Berrueco, Salamanca; los broches de Sanchorreja, Ávila; jarros de bronce, como el hallado en Coca, Segovia, etc. Tal vez la ausencia de thymiateria esté indicando que, en sus muy varias ceremonias religiosas, no tenía cabida la quema ritual de compuestos vegetales aromáticos. O bien lo hacían en vasos de barro o perecederos. Entre las vasijas que constan en los registros de los diversos yacimientos de tinte indoeuropeo excavados, o producto de prospecciones, aparecen fragmentos más o menos grandes, que no tienen una definición clara, -algunos pertenecen a receptáculos de planta cuadrada- , y quizá deban adjudicárseles, efectivamente, aquel cometido. Esta última hipótesis la aplicamos además a algunos objetos extraños de los catálogos arqueológicos, generados por la investigación de depósitos adscritos a la cultura ibérica; además, y para esta civilización, y en escasos yacimientos, se han llegado a encontrar las características cabezas, de tipo griego y cartaginés, las llamadas "Tanit", que pudieran haber sido utilizadas para quemar sustancias aromáticas, y que tan frecuentes son en el área fenicio-púnica de lbiza. Desde los orígenes de la cultura ibérica no podían faltar rituales en los que participaran los sahumerios, porque un gran segmento de la religiosidad y los rituales correspondientes, son derivaciones de los de tiempos tartésicos. Pero las ostentosas piezas fenicias, los thymiateria, para producir aromas, bien para purificación, bien en honor de las divinidades, bien en honor de los muertos, etc., sólo las detectamos en el floruit del entorno colonial del mediodía peninsular, con ramificaciones, y por extensión de los circuitos comerciales orientales, hacia los parajes mineros del hinterland tartésico, la Alta Andalucía, Extremadura y sur de Portugal.

Los thymiateria suelen ser de diversas formas -en este escrito no tiene cabida su análisis, revísese el estudio de J. Jiménez Ávila (2002)pero hay un elemento indispensable que es la taza o cazoleta, generalmente con tapadera, y ésta con asidero. En la cazoleta se queman aquellas hierbas o resinas requeridas para el ri- 


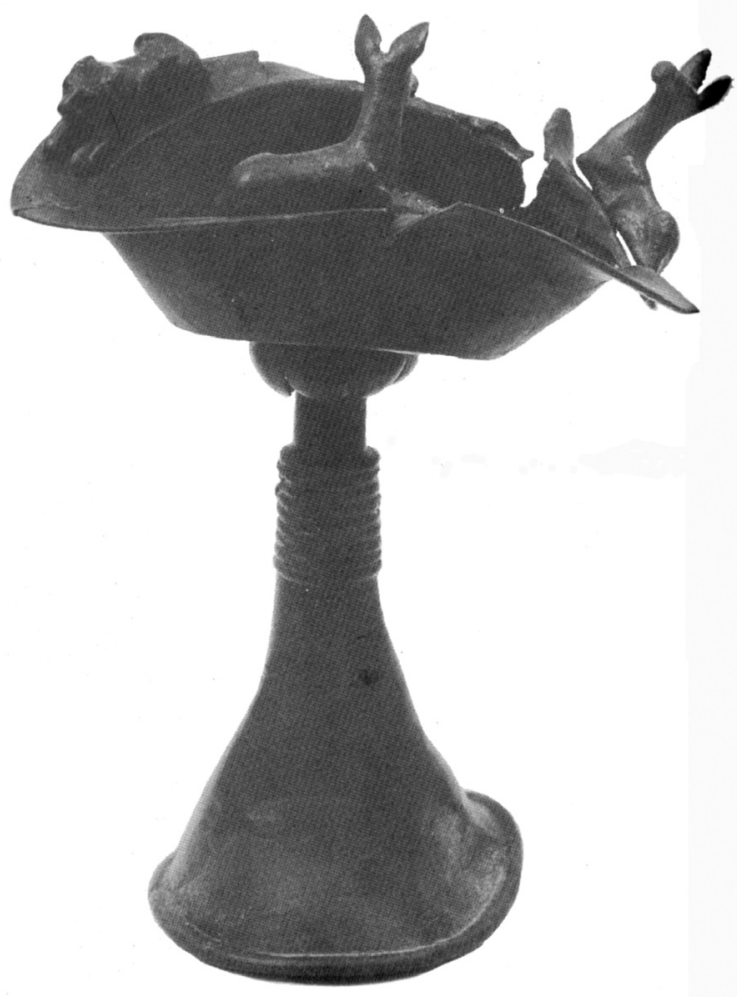

Figura 10: Thymiaterion de Los Higuerones, Castulo, Jaén.

tual que fuere. Los ingredientes utilizados podían ser muy diversos, y según el poder adquisitivo pertinente, y aunque no los conocemos, por la tradición transmitida a través de los siglos, serían los mismos que los empleados ahora, es decir, desde resinas importadas, hasta plantas aromáticas, secas, recogidas en los campos peninsulares.

De todo el conjunto de los quemaperfumes, aquí interesan las tapas de las tazas, y más concretamente los asideros de las mismas. En las tapas se encuentran composiciones sencillas pero que debieron de tener un significado concreto y definido, en relación a los sacrificios en los que intervenía el humo sagrado. Entre las escenas o entre las figurillas individuales de los apéndices de las tapas, aparece el ciervo; y así podemos observar como una parte de la iconografía de los thymiateria se acerca, en cierto sentido, a la de los jarros.

De igual forma, en otros ejemplares, menos complejos, no sabemos si importados, porque no hay elementos materiales suficientes como para clasificarlos, decora la parte superior de la tapa del thymiaterion una sola esculturilla, que es, a veces, un ciervo. La pequeña efigie del ciervo suele estar recorrida interiormente por un conducto que dirige el humo desde la taza a la boca del animal, por la que surge.

A continuación relacionamos todos ellos, con sus particularidades:

- Los habitantes de Castulo, Linares, Jaén, en el Bronce Final, se relacionaron intensamente con los fenicios de la costa onubense, como lo prueban los numerosos restos de cerámica de aquella zona, concretamente de retícula bruñida. ¿Por qué?, porque el área de control de los castulonenses era muy rica en minas de galena argentifera, requerida por los fenicios, directamente o a través de los intermediarios tartésicos. $Y$ de ahí que los señores relevantes adquirieran o recibieran, como don, todo aquello que podían ofrecerles los mercaderes tirios o sus agentes hispanos. Y emplearon, en vida, en los rituales de la religión propia, los thymiateria, "los braserillos", y otros objetos exóticos, llegados de lejos. Los mismos, cuando fue necesario, los destinaban al mundo de la muerte. Y así, los localizamos entre los ajuares de ciertos enterramientos de aquella época o un poco posteriores (nunca en el Castulo de los vivos, por lo expresado más arriba).

En uno de los ajuares de la tumba de un personaje de elevada posición, se recogió un thymiaterion de bronce (Blázquez, 1983, 66-67, il. 31. Jordá y Blázquez, 1988, 217, fig. 12; Jiménez Ávila, 2002, 400, lám. XXX) (Fig. 10). El monumento sepulcral se hallaba situado cercano a la puerta orientada al este, al exterior del hábitat castulonense, en el paraje denominado Los Higuerones, donde se levantaron varias tumbas $^{8}$, espléndidas en cuanto a superestructuras, y suponemos que en cuanto a ajuares (muy perdidos). La cazoleta del thymiaterion en cuestión es circular (los dispositivos de salida del humo son difíciles de ver), con el borde doblado hacia el exterior, $y$ tres animales de bulto redondo sobre él: dos ciervas y un león, sujetos al borde mediante clavos. Las ciervas deberían estar a la expectativa ante el carnívoro, aunque con las pa-

8. La mayor parte de las tumbas, tumulares, de Los Higuerones, exceptuando la que contenía el thymiaterion, y los otros bronces, cronológicamente adscrita al Bronce Final, por la morfología de sus materiales de procedencia fenicia (a no ser que consistan en objetos que se encontraban en poder de una familia desde aquellos tiempos hasta la época ibérica), están datadas en plena época ibérica, entre finales del siglo $\mathrm{V}$ hasta la mitad del siglo IV a.C. Era pues un área sacra funeraria desde aquella lejana fase protohistórica, si es que, efectivamente, la tumba depositaria de los objetos importados pertenecía a gentes de la época del dicho Bronce Final, durante el cual, en Castulo, esto si está bien documentado, existió una población ciertamente densa. 


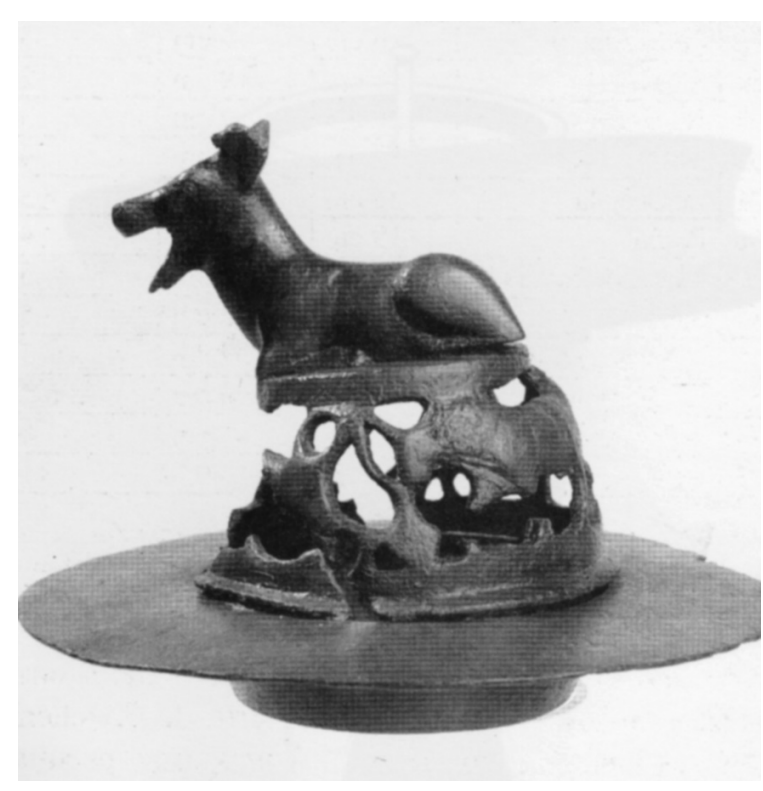

Figura 11: Cazoleta y tapa del thymiaterion de La Lagartera, Cáceres (Foto Novillos, en Jiménez Ávila, 2002).

tas flexionadas, tumbadas, verdaderamente no se las ve demasiado alteradas. Tienen el cuerpo compacto, el cuello alto, las largas orejas erguidas y la boca cerrada, aportando, en conjunto, un cierto aire de naturalismo, que demuestra que el que las fabricó conocía perfectamente al animal y supo copiarlo. La fiera se halla en actitud de alerta, y sus rasgos están más alejados de la realidad. La datación hay que situarla alrededor de la primera mitad del siglo VII a.C. o principios del siguiente.

- Asimismo de Castulo, y de un lugar próximo al de Los Higuerones, en la finca Torrubia, se halló un bloque informe de bronces, fundidos unos a otros. Estuvieron sometidos al fuego del ustrinum. Es de suponer que, formando parte de un ajuar, sufrieron idéntica suerte que el cadáver al que le fueron ofrecidos, lo cual era usual. A las cenizas del cadáver, de las que no se tiene noticia, le fue levantada una tumba, prácticamente desaparecida, que tuvo que ser de importancia, si atendemos a los bronces llegados en tal estado; por las características, debieron constituir espléndidos efectos importados. $Y$ los mismos supondrían una fracción del total del ajuar, consistente, por comparación con otros, en una gran variedad muy heterogénea, de objetos autóctonos e importados, incluyendo ofrendas vegetales y animales. En la masa fundida hay vestigios de un thymiaterion, y entre ellos restos de la taza, cariátides y una figura maciza de mamífero, mirando al frente y con la boca cerrada (Jiménez
Ávila, 2002, 403, lám. XXXV); probablemente será un cérvido, si atendemos al thymiaterion de Los Higuerones, y al particular significado del ungulado en este mundo orientalizante hispano, aludido en varias ocasiones.

- Perteneciente a un thymiaterion puede ser un bronce de Jaén que representa un ciervo de pie, sobre el que se apoya la parte central del recipiente.

- En otra región, Cáceres, finca de La Lagartera, se halló la cazoleta y tapa de un thymiaterion (Fig. 11). El lugar del hallazgo pudo haber sido una estructura tumular funeraria, desmantelada, con lo cual el thymiaterion se situaría en función del enterramiento cubierto por el dicho túmulo. Nuevamente, como en los ejemplares de Castulo, sólo hacemos mención a la tapadera de la cazoleta, en cuya parte superior hay un ciervo que resaltaría espléndidamente en el pebetero. Es de bulto redondo, modelado con detalle. Como tiende a ser un canon, está echado con las cuatro patas flexionadas, ya lo hemos visto con respecto a las ciervas del thymiaterion de Los Higuerones, y veremos en otros ejemplares; la boca abierta y la lengua hacia delante, sobre el belfo inferior; las orejas son altas, y están fracturadas, le faltan las defensas. Esa boca abierta, que se repite en la mayoría de los cérvidos que estamos estudiando, parece estar recreando la berrea, de la época de la brama, aunque en la realidad, cuando el animal la emite, no saca la lengua, pero sí levanta la cabeza, como puede observarse en la figura 1. El cuerpo es hueco. Se comunican cabeza (boca) y

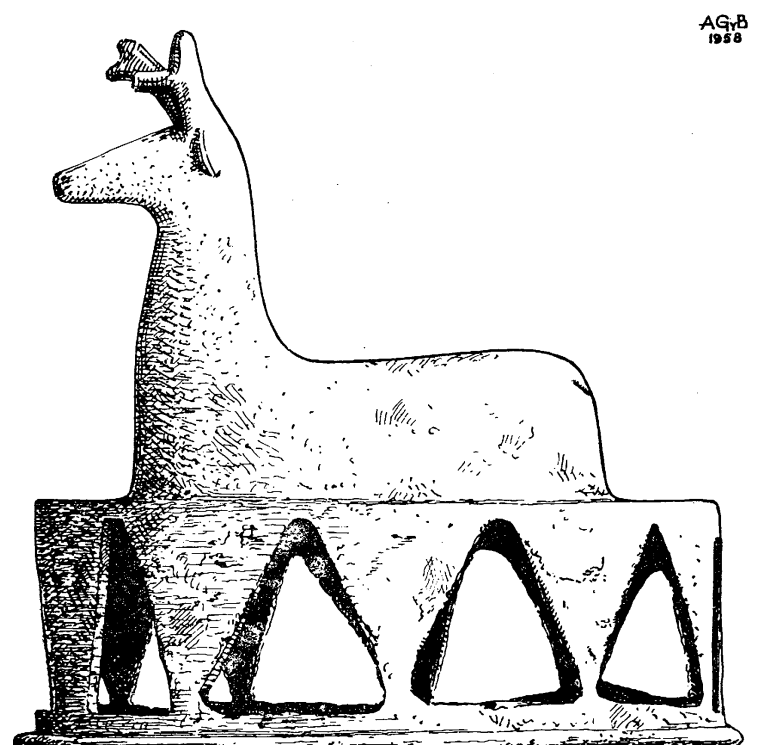

Figura 12: Tapa de la cazoleta del thymiaterion de La Codosera, Badajoz. (Dibujo García y Bellido, 1957). 


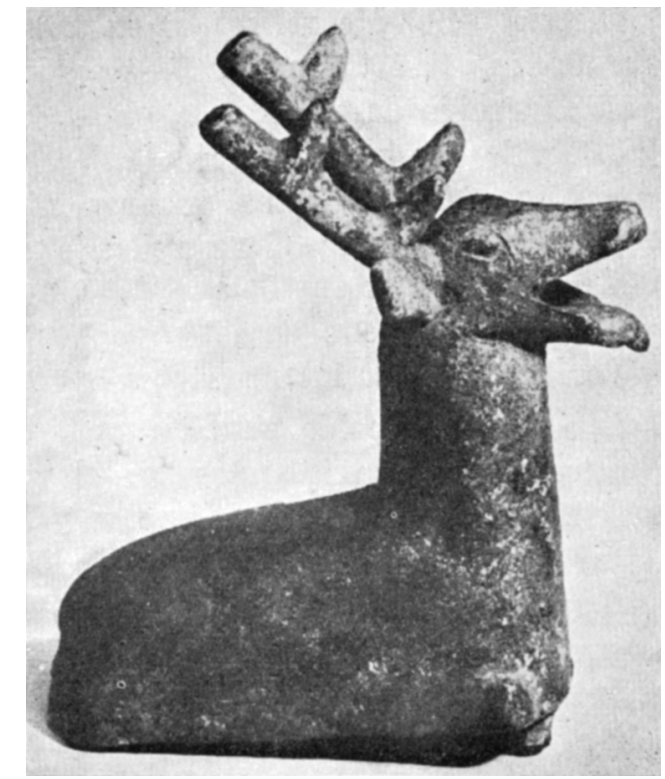

Figura 13: Agarre/adorno de un thymiaterion (perteneció a la Colección Calzadilla, ahora depositado en el Museo Arqueológico de Badajoz) (Foto García y Bellido, 1957).

cuerpo, y éste, a su vez, se comunica con la base de la plataforma, sobre la que se halla el ungulado. De esta manera el humo sería expulsado por su boca, y parte surgiría por entre los calados de la zona central. Al respecto de esta última, consiste en un ancho friso calado, con un motivo, en bajorrelieve, repetido dos veces: un león atacando a un toro (Jiménez Ávila, 2002, 403-404, fig. 105, lám. XXXVI; 2005, 1107, fig. 11), escena claramente oriunda del Próximo Oriente, no así el ciervo, que seguimos suponiendo, es una decoración específica peninsular y más concretamente del cuadrante suroeste andaluz y sur de Extremadura y Portugal.

- En el término de La Codosera, Badajoz, sin otro detalle en la localización, se halló la tapa de la cazoleta de un thymiaterion (Fig. 12), cuyo concepto, en cuanto al ciervo y en cuanto a su situación en el accesorio del incensario, es el mismo que el del ejemplar de La Lagartera, aunque en el ciervo de La Codosera domina una total imprecisión con respecto a cualquier rasgo naturalista. Consta de un pedestal cilíndrico perforado por diez huecos triangulares. Sobre este pedestal reposa, tumbado, un ciervo, se supone, sólo se supone, sobre las patas flexionadas. El cuello está erguido; las cuernas son anchas y con simplicidad de líneas; las orejas cortas y la boca cerrada; no hay detalles anatómicos más específicos. El interior del cuerpo es hueco (Jiménez Ávila, 2002, 404, lám. XXXVII; 2005, 1106, fig.10.1).
- Un ciervo de bulto redondo se hallaba en la Colección Calzadilla (Fig. 13). Igual que el resto de los determinados líneas arriba, debió constituir la parte más superior de un thymiaterion, es decir el agarre/adorno de la tapa de la cazoleta, donde se quemaban las hierbas y/o resinas olorosas. A tal efecto la pieza es hueca, y posee un canal, que comunica el cuerpo con la boca, ésta abierta, por la que saldría el humo, como repetimos ya varias veces acerca de otros thymiateria; eso sí, siempre y cuando la plataforma (perdida), sobre la que debía reposar el ciervo, estuviera perforada, igual, por lo menos, que la del ejemplar de La Lagartera. El ciervo está tumbado con las cuatro patas flexionadas sobre el abdomen, la postura preceptiva; tiene el cuello erguido, con altas y ramificadas cuernas de dos puntas; las orejas grandes, alertas, y la boca, según describimos, abierta, con la lengua fuera sobre el belfo inferior (Jiménez Ávila, 2002, 404, lám. XXXVII; 2005, 1106, fig.10.2).

- Una pequeña figura de cierva, en bulto redondo, se encuentra en el Museu Nacional de

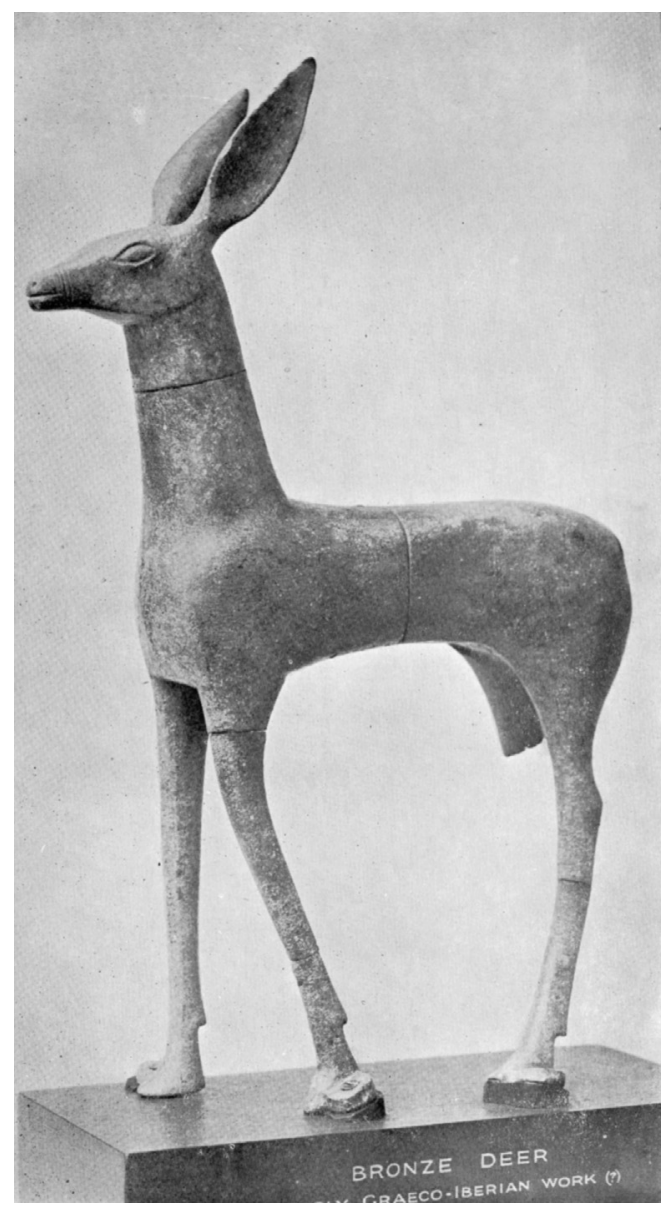

Figura 14: Cierva del British Museum (Foto García y Bellido, 1957). 


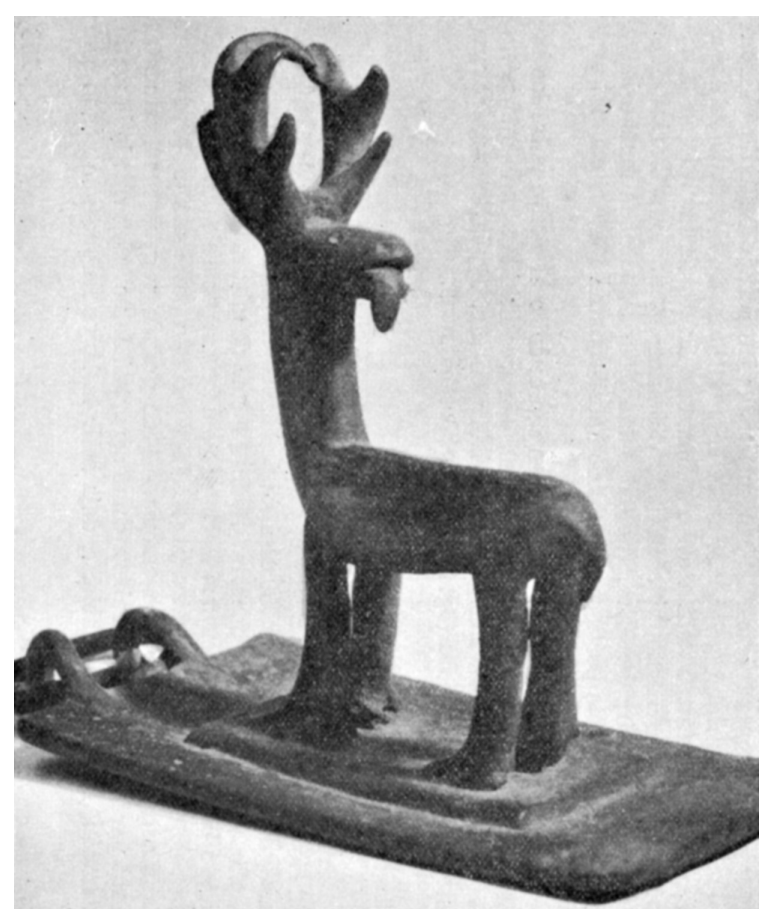

Figura 15: Ciervo de Coruche, comarca de Riba Tejo, Portugal (Foto García y Bellido, 1958).

Arqueologia e Etnologia de Belém, sin origen conocido, aunque J. Jiménez Ávila (2002, 404, lám. XXXVII) no descarta una procedencia del sudeste peninsular. La cierva está tumbada, y según palabras de este investigador (2002, 404):" mirando en dirección transversal al cuerpo. Se representan las patas, dobladas a ambos lados del cuerpo, las orejas, la cola y los ojos redondos". Podría ser, igualmente, el agarre de la tapa de la taza de un thymiaterion.

\section{c) Figuras exentas}

Acerca de la figurilla de cierva, depositada en el British Museum (Fig. 14), que detallaremos en seguida, y de otras piezas de bulto redondo, ciervos machos y hembras, todas sin contexto determinado y todas de bronce, A. García y Bellido $(1957,127)$ opina que son exvotos. Con la dicha creencia estamos, aproximadamente, conformes, aunque hemos de significar que la mayor parte de los santuarios en los que se ofrecían exvotos, pertenecen cronológicamente a la cultura ibérica, y no a tiempos anteriores, como parece que deben situarse estas figuras. En cambio de la sierra de Vilches, Jaén, sin origen preciso, en las cercanías de una zona rica en santuarios ibéricos en cuevas, como es la de Despeñaperros, proviene un pequeño ciervo de bronce sobre peana, de la que salen dos cabecitas de cervatillos (en paradero ignorado), cuya estética se acerca más a la ibérica que a la de periodos anteriores. Por la coincidencia con los santuarios próximos, esta pieza sí podría constituir un exvoto que, o bien no llegó a su destino, o se desvió del lugar sacro en el transcurso de los siglos. Y si tal fuera, porque en la comarca hay manchas de bosques frondosos, más en tiempos pasados y, por tanto, fauna salvaje abundante, estaría en relación directa con la caza y con el cazador, que ofreció un exvoto de tales características, para conseguir buenos ejemplares, o porque los había conseguido, o porque salió indemne de un mal lance cinegético, o por cualquier otra circunstancia. Evidentemente hay otras alternativas al respecto del significado del conjunto de Vilches, pero sólo esgrimimos el dicho porque en estas líneas aludimos, tangencialmente, a los lugares sacros ibéricos, en los que se han recuperado cientos y cientos de pequeños exvotos de bronce. Empero, la referida cierva del British Museum, por su magnitud, y majestuosidad, mide $30,5 \mathrm{~cm}$, de alto (García y Bellido, 1957, 126, 127, fig. 11. Jordá y Blázquez, 1988, 218-219, fig. 8), no es probable que sea un exvoto. Aunque no hay un acuerdo absoluto sobre su cronología, la data M.C. Fernández Castro, a finales del siglo VI o principios del $\mathrm{V}$ a.C. $(1989,128)$, y uno de nosotros (Blázquez) a finales del siglo VII o principios del VI a.C. El animal, de admirable factura, elegante, camina erguido, con la boca cerrada y con grandes orejas empinadas.

Tampoco la cierva de Madrid parece ser un exvoto [forma parte de una colección particular, estudiada por R. Olmos (1992, 41-64) y recogida en la obra de J. Jiménez Ávila (2002, 269-270)]; tiene las mismas particularidades que la anterior, aunque aquí la lengua cuelga, sobre el belfo inferior.

Una teoría acercaría a una y otra a ser imágenes de culto, no por sí mismas, sino por representar el animal emblemático, particular del dios o de la diosa, de la vida y la muerte a los que nos referimos líneas atrás. Ambos, por su inmensidad, no podían ser contenidos en la materia. El aniconismo hacia los dioses supremos, el adorarlos sin que se hallen explícitamente figurados en efigies, tiende a ser natural en numerosas religiones primordiales sencillas $o$ desarrolladas complejas, de épocas antiguas y de épocas actuales, adviértase la musulmana o la cristiana.

Otras esculturas, todas de pequeño tamaño, son las relacionadas seguidamente: 

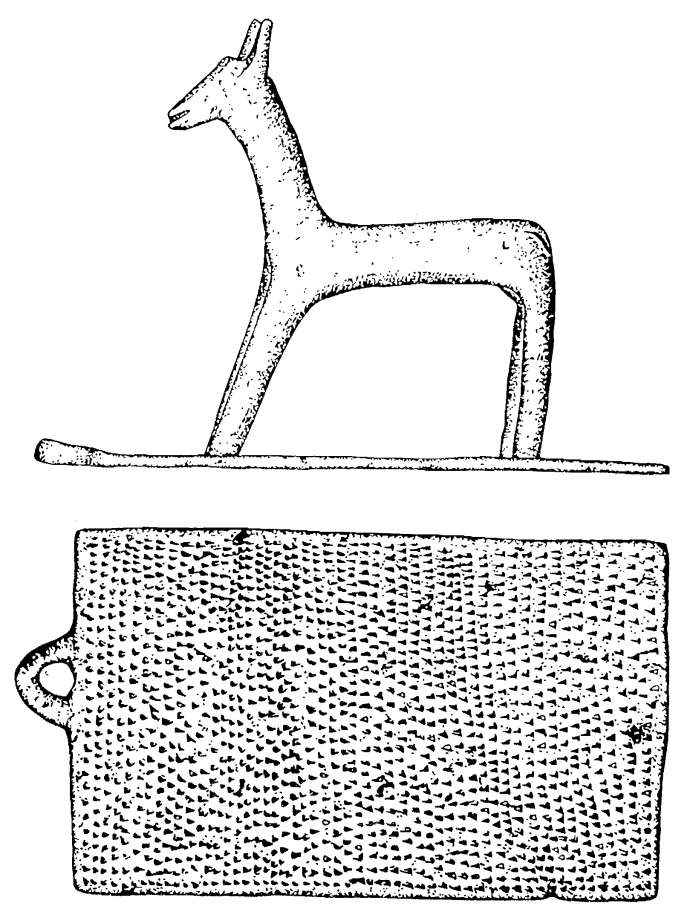

Figura 16: Placa con cervatillo de Cancho Roano, Zalamea de la Serena, Badajoz (según Celestino y Jiménez Ávila, 1996, en Jiménez Ávila, 2002).

- De Coruche, comarca de Riba Tejo, Portugal, procede un bronce, de pequeño tamaño, $10 \mathrm{~cm}$ de alto, que representa un ciervo, sobre doble placa, con anillas de suspensión por uno de los lados (Fig. 15). Las características anatómicas del animal son vagas, hay desproporciones, como el largo cuello en relación con el cuerpo. No obstante, el concepto general está bien expresado. El ungulado tiene la cabeza vuelta hacia atrás, con unas poderosas cuernas ramosas coronándola; la boca abierta, y una larga lengua pende hacia un lado del belfo inferior. ¿Podría ser un exvoto como cabe la posibilidad de que lo fueran los ciervos de Vilches, también sobre un soporte? es una suposición como lo es para el objeto de Vilches, pero nada más. No creemos sea una figurilla de culto, como sí parece lo serían las ciervas del British Museum y de Madrid.

- En el lugar denominado Marroquíes Altos, en la ciudad de Jaén, apareció, al realizar unas construcciones, entre otros objetos arqueológicos, datados desde el Eneolítico a la época romana, un ciervo de bronce $(14 \mathrm{~cm}$ de alto $\times 12$ $\mathrm{cm}$ de largo), como el de Coruche sobre una lámina rectangular (Blanco en Luzón y León, 1996, 289, fig. 6). E igual que éste se encuentra parado, con las patas bien definidas, con un cierto sentido naturalista en ellas, no así en el cuerpo; el cuello está erguido, la cabeza levantada al frente, no vuelta como en el ejemplar de Coruche; y la boca abierta, en actitud de berrea (falta la mandíbula inferior y la lengua, si es que la tenía); las orejas son largas; las defensas apuntan, pero están fragmentadas. El ciervecillo lleva soldado a su grupa un tubo rectangular, incompleto, que probablemente sostendría otro aditamento. A. Blanco (Luzón y León, 1996, 289) señala la hipótesis que soportaría "una lámpara o un incensario comparable al thymiaterion de Calaceite". El accesorio, mantenido por el tubo, no podría tener mucho peso, ya que, en otro caso, el animal, a pesar de hallarse sobre la dicha plataforma, se levantaría por la parte delantera

\section{d) Objetos diversos}

Para nuestro estudio contamos con ciertas piezas, escasas, que en su composición, contienen la figura del ciervo, y de las cuales, en realidad, no se conoce la funcionalidad, excepto un kernos, y de éste aproximada. Las relacionamos aquí.

Han sido también encontradas en el cuadrante suroccidental andaluz y sur de Extremadura y Portugal. Parte, pues, ya es sabido, de la región que en la Protohistoria tardía estuvo poblada por los lusitanos históricos. $Y$ tiempos atrás, durante el Bronce Final, y aún antes -atiéndase a las decoraciones incisas de las llamadas "estelas extremeñas"-, aún pecando de repetitivos, constituyó una tierra en conexión con las corrientes comerciales del Próximo Oriente, y por ende

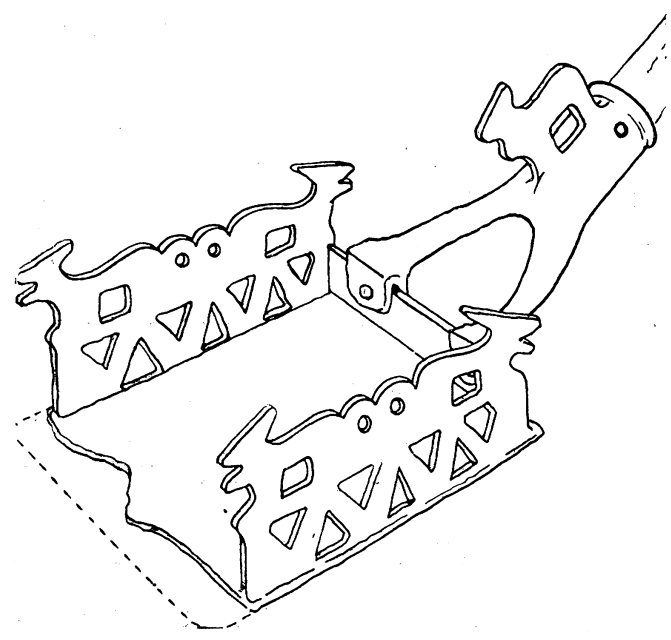

Figura 17: Paleta de posible uso ritual, depositada en el Museo Arqueológico Nacional de Madrid (Dibujo García y Bellido, 1957). 


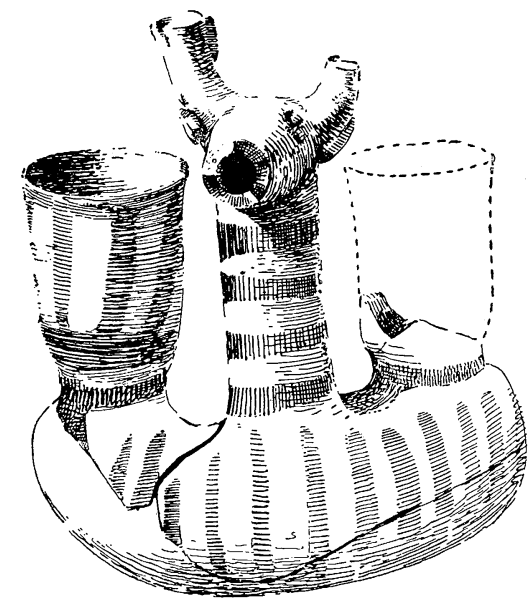

Figura 18: Kernos de barro, Mérida, Badajoz (Foto García y Bellido, 1957)

culturales, además de constatarse comunicación con otras regiones. Este último hecho es usual entre la mayor parte de los pueblos, primitivos y no tanto, cuya movilidad siempre ha tendido a ser ampliamente acusada. Y exclusivamente hay una opción, bien que vaga, para determinar las interrelaciones Península Ibérica-Próximo Oriente, son los objetos estudiados en los apartados superiores, -un gran número encontrados en el territorio dicho, como han de observar los que lean estas líneas-, y los que se estudian a continuación:

- Ciertamente, el mejor testimonio es el colosal "palacio-santuario" de Cancho Roano, Zalamea de la Serena, Badajoz, cuya primera fase constructiva se data en el siglo VI a.C., con pervivencia, en sus distintas fases, hasta el primer cuarto del siglo IV a.C., en que fue incendiado, después de otros varios fuegos (Maluquer, 1981-1982. Celestino y Jiménez Ávila, 1996, con amplio aparato bibliográfico).

- Entre los objetos muebles asociados a la monumental construcción de adobe, consta una pequeña placa rectangular de bronce, con anilla en uno de los lados cortos. Sobre la placa se yergue un cervatillo, trabajado con economía de líneas (Fig. 16). Según J. Jiménez Ávila (2002, 261) puede tratarse de la tapa de una caja de madera o marfil.

- Un elemento mueble de difícil interpretación, que ha sido objeto de diversas valoraciones, consiste en una especie de pala de bronce, depositada en el Museo Arqueológico Nacional de Madrid (Fig. 17). Ha sido estudiada por A. García y Bellido (1957, 125-126, figs. 17-19; 1958, 163), y por uno de nosotros (Blázquez). No se conoce su origen primero, aunque A. García y Bellido $(1957,126)$, por los ciervos integrados en su de- coración, opina que "procede de Lusitania". Está formada por una plancha plana, como base, y tres bordes laterales del mismo material. Las paredes laterales ofrecen en recorte dos ciervos, que se dan la espalda. Por debajo de estas siluetas se abren, en calado, siete triángulos. El brazo de la pala es cilíndrico. Sobre él hay un ciervo. Acaso fuera un utensilio de culto, y responde a prototipos de Luristán, y de Hauran, Siria, fechados el primero, siempre según A. García y Bellido (1958, 163, fig. 12), hacia fines del II milenio a.C., y los de Hauran en tiempos romanos. En los bronces de Hauran los ciervos, que se hacen presentes en los de Luristán y Península Ibérica, están sustituidos por grifos alados (García y Bellido, 1957, 130 , figs. $17-19 ; 1958,163$, fig. 12). Las palas, cree A. García y Bellido $(1957,126)$ que servirían como badilas para manipular en un fuego ritual; $y$ uno de nosotros (Blázquez) para recoger las cenizas resultantes de la cremación de los cadáveres. ¿O por qué no pudieron ser utilizadas, si es que son rituales, y siguiendo en la misma línea que $A$. García y Bellido, para reunir y retirar cenizas provenientes de sacrificios animales o vegetales, en honor de los dioses o a favor de los difuntos, para protegerlos en aquello que conviniera, de acuerdo con las creencias propias sobre el Más allá? Pero bien es verdad que el argumento de los sacrificios, de los rituales, está más que trillado para explicar cualquier concepto, cualquier material, acerca de cuyo significado o de cuyo uso no tenemos ni la más mínima idea. De todas formas ahí se encontraría nuevamente el ciervo como animal entroncado, tal vez, con el ámbito de ultratumba. $Y$ nuevamente entre los ascendientes de los lusitanos históricos, porque aunque carece de contexto geográfico y cronológico, por la calidad de las decoraciones, podría proceder del comercio fenicio, y, entonces se situaría en el Bronce Final.

- La lámpara cerámica de tipo kernos, descrita ahora brevemente, procede de las inmediaciones de la Alcazaba de Mérida, Badajoz (García y Bellido, 1957, 124, fig. 16) (Fig. 18). Sobre un anillo circular van dispuestos dos vasos entre los cuales se alza un ciervo. Según uno de nosotros (Blázquez), su fecha es del siglo VI a.C. Es de pasta blanquecina, decorada con pintura rojiza, almagre, a base de franjas verticales, relativamente paralelas.

\section{EL CIERVO EN MONUMENTOS FUNERARIOS IBEROS}

- En una de las necrópolis del oppidum oretano de Castulo, la del Estacar de Robarinas, datada 


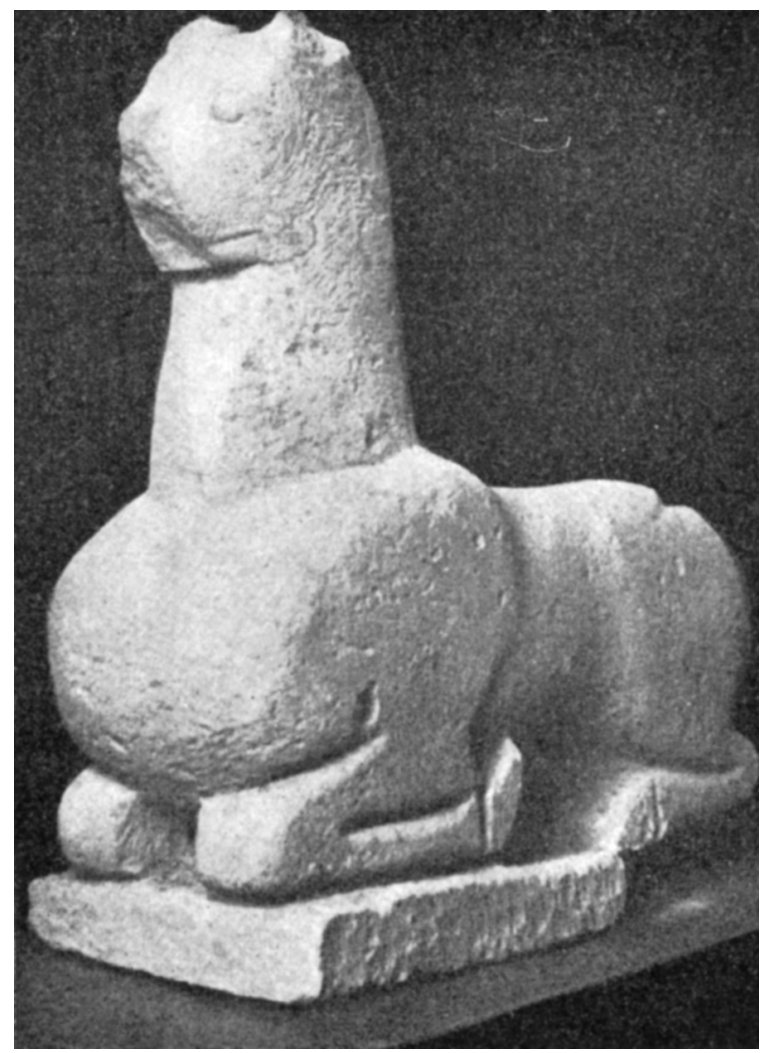

Figura 19: Cérvido de la necrópolis de Caudete, Albacete (Foto García y Bellido, 1958).

aproximadamente desde finales del siglo $\mathrm{V}$ hasta la mitad, del siglo IV a.C., en el transcurso de la campaña de excavación de 1976, se halló una construcción funeraria. Parecía ser un túmulo escalonado, muy deteriorado, en cuyo centro existía una cámara rectangular excavada en la roca madre, y con las paredes revestidas a base de lajas rectangulares, regularmente careadas. La cámara fue saqueada, por lo menos en dos ocasiones. La primera, abriendo un agujero en el ángulo NW, cuando el túmulo estaba aún en pie; y una probable segunda vez, destrozando la pared este hasta la base. Una de las violaciones, supuestamente, ha de documentarse en fechas romanas, puesto que se halló TSH junto a la cerámica ibérica, aunque es este un argumento indudablemente frágil.

Al aislar el monumento se constató en la cara oeste una apreciable cantidad de fragmentos de esculturas, algunos muy menudos, de cérvidos (podrían componer alrededor de cuatro hembras), de toros, y quizás de más animales, caídos delante de los escalones (Blázquez y Remesal, 1979, 363, láms. XLII, XLIII.1). El hallazgo impulsa a hipotetizar que en este frente se alzaba, exento, o adosado parcialmente, un grupo escultórico compuesto, al menos, por los animales citados.

El dicho grupo escultórico debió sufrir idéntica suerte que otros muchos del área ibérica, es decir fueron triturados con ferocidad. ¿Motivo?, desconocido, aunque, y esto es irrebatible, la salvaje iconoclastia fue dirigida a los monumentos de los cementerios, uno de los signos externos de la clase dominante. Pudiera ser que, atacando a los muertos preclaros, es decir a sus tumbas, se atacara, en cierta manera, al orden establecido por los dirigentes vivos, descendientes de aquellos que ya vivieron; y eso que el universo de la muerte, por regla general, siempre fue respetado incluso en épocas bélicas, debido a su muy especial carácter sagrado.

Los autores no indican si en la cámara de Robarinas hallaron restos humanos cremados, el ritual predominante en aquella civilización y en la necrópolis. Únicamente registraron, en el perfil norte, un cadáver, inhumado, colocado en posición fetal, sin ajuar. Como hipótesis de trabajo podía pensarse en un sacrificio humano dedicado a los supuestos ocupantes de la tumba; o en un enterramiento más tardío (Blázquez y Remesal, 1979, 363, 366).

Un dato añadido es el relativo a que hacia la cara oeste apareció una cista cenotáfica, destinada al cadáver de una mujer (por las piezas constituyentes del ajuar) que por circunstancias no pudo enterrarse (Blázquez y Remesal, 1979, 364-366).

Las ciervas, y los restantes animales, que presumiblemente constituían la zona frontal del sepulcro, es muy verosímil que tuvieran un carácter bienhechor de la calidad que fuere, no de la superestructura sepulcral, sino de los cadáveres que guardaba. Así pues, nuevamente constatamos al ciervo en medios funerarios. Y esta vez en la civilización ibera. En realidad, pues, en esta época ibérica tendría el ciervo semejantes virtudes, para los que mueren, que en la del Bronce Final orientalizante: ¿bienhechor, protector, mediador, ser que aporta esperanza de renovación de la vida en el Allende? Cualquiera de estas posibilidades podría ser válida si efectivamente lo fueron en las remotas fechas del Bronce Final aludidas. Así pudo ser, teniendo en cuenta que, evitando complejidades de derivaciones, que las hay, los iberos, culturalmente, y lo venimos repitiendo, remontan un segmento de sus orígenes, a la civilización llamada genéricamente tartésica, en la que sí parece que el ciervo tuvo algunas de las dichas atribuciones, por lo menos con calidad adyacente, según la teoría determinada líneas atrás. 

citada:

No hay ciervos solamente en la necrópolis

- En los museos de Jaén, Córdoba y Albacete, entre otros, se conserva una buena colección de estos ungulados, colocados arriba de plintos, tumbados con las patas flexionadas, sobre el abdomen, que probablemente pertenecieron a monumentos funerarios iberos. Algunas esculturas están muy dañadas, faltándoles, sobre todo, la parte más delicada, la cabeza, o parte de ella. En realidad se hallan en idéntica posición a como están representados en la toréutica oriental, lo que refuerza, en cierto sentido, la opinión de investigadores, como J. Jiménez Ávila (2002, 343) y nuestra, de que la vieja iconografía del animal, en la broncística, fue encargada por las élites nativas a los talleres de Tiro, o a talleres tirios instalados en el mediodía peninsular, en razón de una serie de creencias al respecto del animal; también pudo ser que sencillamente imitaran las actitudes del animal que pudieron conocer a través de los bronces antiguos.

- Un ejemplar interesante, por su excepcional conservación para el periodo al que pertenece (la mayor parte dañados brutalmente),

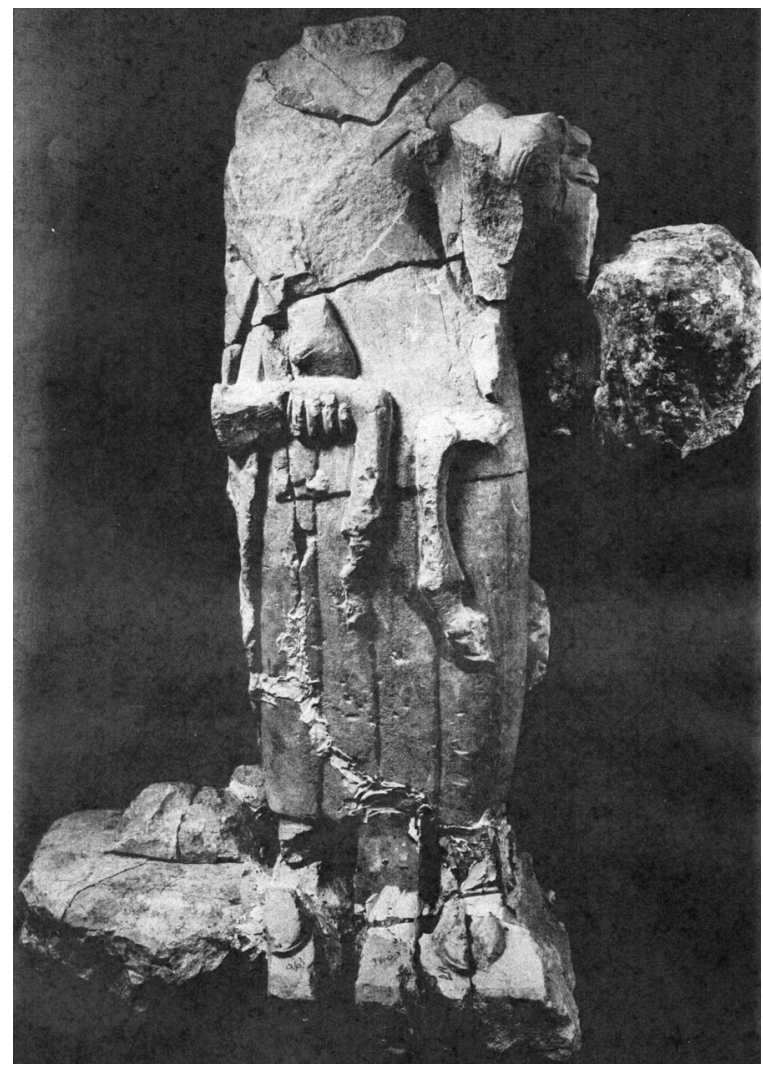

Figura 20: Escultura del Cerrillo Blanco, Porcuna, Jaén. Vista frontal (Foto Instituto Arqueológico Alemán, Madrid, en González Navarrete, 1987).

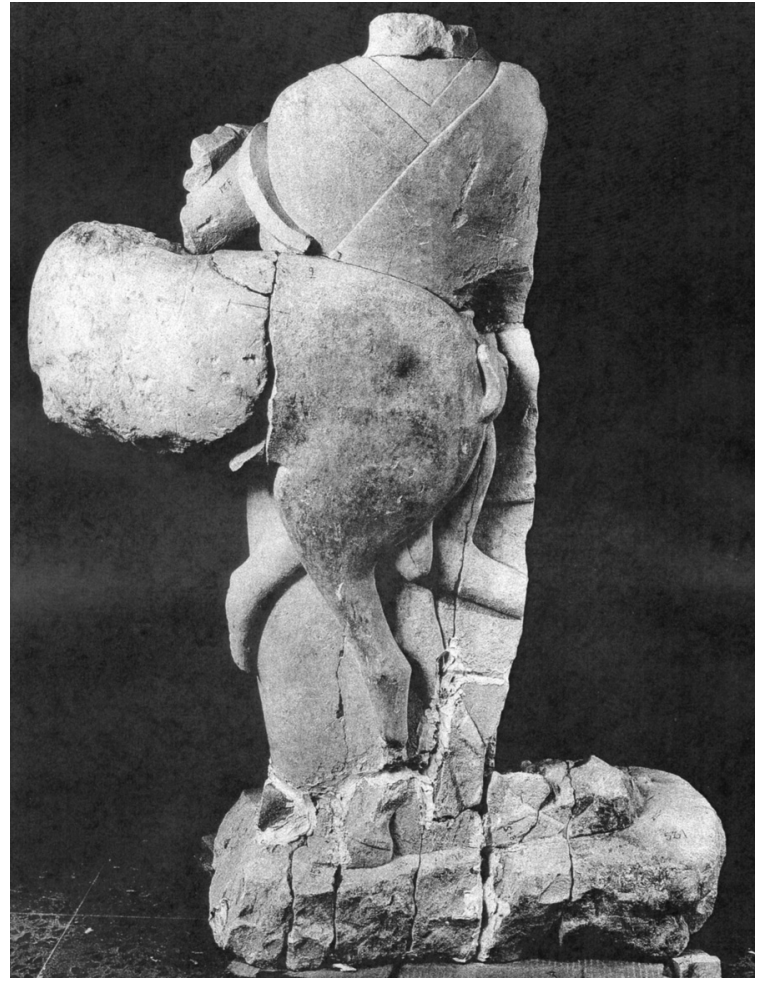

Figura 21: Escultura del Cerrillo Blanco, Porcuna, Jaén. Vista dorsal (Foto Instituto Arqueológico Alemán, Madrid, en González Navarrete, 1987).

es el ciervo -macho o hembra9 ${ }^{9}$ de la necrópolis de Caudete, Albacete (Fig. 19). El animal, de tamaño apreciable, con respecto a los conocidos, mide $77 \mathrm{~cm}$ de alto, se encuentra echado, en la característica postura: flexionadas las patas sobre el abdomen y colocado sobre un plinto (García y Bellido, 1958, 160-161, figs. 7-11; Blázquez, 1983, il. 80). Carece de naturalismo.

- Una segunda pieza, con las mismas particularidades, se encontraba en las inmediaciones de la anterior, además de restos de varios animales más, como un toro y otros cuadrúpedos (García y Bellido, 1958, 161). Este autor (1958, 161, figs. 7-11) fecha la necrópolis dentro de los dos últimos siglos anteriores a nuestra Era, y nosotros (Blázquez) entre los siglos IV, III a.C.

- En la necrópolis de Toya, Peal de Becerro, Jaén, se halló la escultura de una cierva (acéfala) tumbada sobre plinto.

- Entre las esculturas que forman parte del supuesto heroon del Cerrillo Blanco, en la anti-

9. La cabeza está mutilada, faltándole el hocico, las orejas y, en el caso de que fuera un macho, las defensas. $Y$ porque la escultura está trabajada con acusada falta de naturalismo, sin los aditamentos, que han sido eliminados mediante golpes contundentes, no es posible determinar sexo. 
gua Obulco (Porcuna, Jaén), se halla la de un varón con las peculiaridades destacadas a continuación (Figs. 20 y 21). I. Negueruela (1990, 242-244), cree que sería un moscóforo. Según uno de nosotros (Blázquez) la figura, probablemente, representa a un dios, de pie, con túnica hasta los pies y manto, constituyendo una versión original del despothes theron. El personaje sujeta dos animales contrapuestos por la espalda, cuyas patas sostiene por delante. Los mismos parecen tener cuernos de cáprido y cuerpo de ciervo, desde luego la morfología del cuerpo se aproxima más a la de los cérvidos que a la de los cápridos. A. Blanco, acerca de la especie de los animales escribe (1996, 574): "El hecho es que las cuernas del animal mejor conservado no dejan lugar a dudas de que se trata de cabras, lo que es muy de celebrar, porque si tales cuernas faltasen, el esbelto tipo de los animales y la enorme longitud de sus patas nos inducirán al error de creer que eran ciervos..."

De la misma idea, acerca de su atribución como personaje divino, es M.C. Marín Ceballos (2000-2001, 187), aunque para esta autora, como para I. Negueruela $(1990,242.244)$, los animales pertenecen definitivamente a la familia de los cápridos. A. Blanco (1996, 575-576) considera que "el "Oferente" de Porcuna dista mucho de sus congéneres y pudiera no ser tal, sino la divinidad misma en una composición heráldica, de simetría bilateral... En Grecia un dios acompañado de cabras sería Pan; en Iberia el más indicado sería el dios de la guerra a quien Estrabón llama Ares y a quien dice que los lusitanos (jsiempre los lusitanosi) sacrificaban machos cabríos...". Uno de nosotros (García-Gelabert) se sitúa, con ciertas dudas, en nuestra disciplina la duda es una constante, en similar opinión que este insigne investigador, debido a que en Cerrillo Blanco prima, entre los grupos escultóricos el carácter heroico, representándose, sobre todo, luchas entre guerreros. Y un dios guerrero "no estaría fuera de lugar en estos contextos" (Blanco, 1996, 576). Aunque bien es verdad que, asimismo, hay otro tipo de escenas en relación con mitos, patrimonio de las culturas mediterráneas de la época -no perdamos de vista que las esculturas fueron realizadas, tal vez, por escultores griegos- como una Grifomaquia, una Leontomaquia. En contraposición, hay escenas más relacionadas con la cotidianeidad, como el pugilato de dos varones; cazadores, uno con liebre, otro con dos perdices; lobo atacando un cordero; un carnicero mordiendo un novillo (Negueruela 1998, 170-171). Pero por lo demás, he ahí que podría estar representada, también, la Diosa de la Fecundidad en este caso figurada en una escultura con serpiente en el hombro, y en otra escultura con un niño desnudo.

De una forma u otra, en este ambiente tan oscuro que constituye la religión de los pueblos iberos, queda abierta la suposición de que el portador de los dos cuadrúpedos, sea una deidad sobresaliente. Así pues, por qué no, entre otras probabilidades, el dios de la guerra, propuesto por A. Blanco, o el paredro de una diosa de la fecundidad, cuya presencia, la de la diosa, hubo de tener, siempre con las máximas reservas, un lugar preeminente en el panteón politeísta ibero.

No todas las esculturas del Cerrillo Blanco debieron esculpirse al mismo tiempo, pero sí a lo largo del siglo $\mathrm{V}$ a.C.

\section{EL CIERVO EN LA PINTURA VASCULAR IBERA TARDÍA}

La pintura vascular figurativa de la fase ibérica tardía representa algunos episodios en los que el ciervo macho o hembra es parte integrante.

Rigurosos investigadores de la cultura ibérica han vertido diversas hipótesis, de todos conocidas, acerca del significado de las pinturas fijadas en la cerámica, y a ellos remitimos. Nosotros (García-Gelabert) opinamos que las escenas, salvo algunas complicadas, y de contenido complejo y alcance trascendente, son muy simples, y tienen un carácter eminentemente narrativo sin contenido alguno espiritual. Es decir, que aquí el ciervo no tiene más significado que el estrictamente ornamental, recreando, eso sí, algunas de las vivencias, de las actividades, de las realidades, en las que se movían los iberos.

Únicamente relacionamos un corto elenco de vasos o fragmentos, con decoraciones, en los que el ciervo, sí no protagonista único, que nunca lo es, si es uno de los componentes:

- Fragmento de un vaso del Castelillo de Alloza, Teruel, en el que en un evento de caza, participan un jinete, lanza en ristre, dos ciervos y, al menos, un carnívoro (Pericot, 1979, 258, lám. 417).

- Fragmento de un vaso de La Monravana, Valencia. En el mismo, además de un pájaro, hay dos ciervas (Pericot, 1979, 181, lám. 275).

- Vaso de San Miguel de Liria, Valencia, con dos escenas en las que intervienen ciervos. En una pacen plácidamente una cierva con su cría, ésta en actitud de mamar, y detrás un ciervo "tranquilo". Es una situación absolutamente irreal, porque los machos, excepto en la época de la brama, viven fuera de los territorios de las hembras. En la segunda un cazador a caballo 


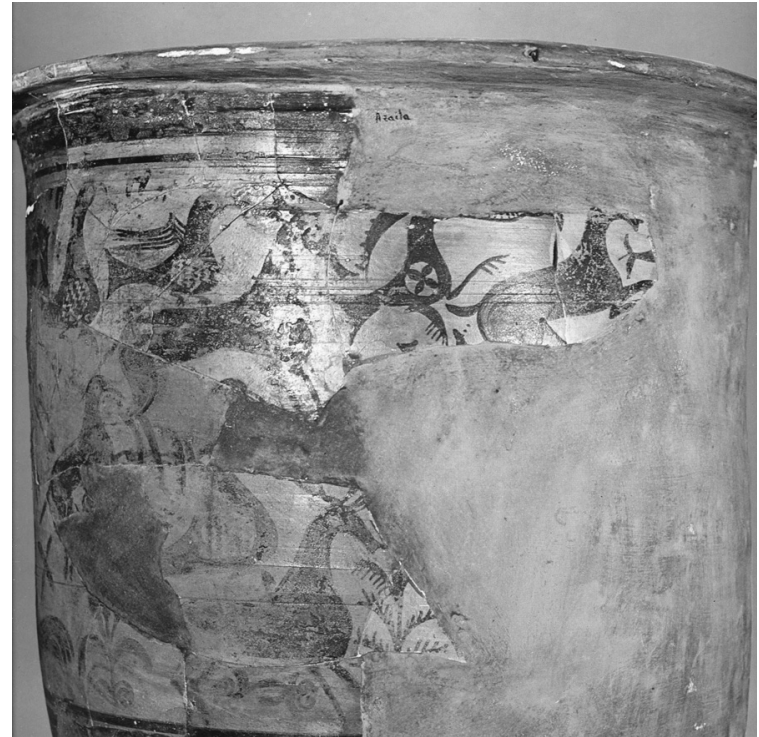

Figura 22: Kalathos de Cabezo de Alcalá, Azaila, Teruel (Foto Pericot, 1979).

arroja lanzas o dardos a una cierva que ya lleva clavado uno en el flanco (Pericot, 1979, 150, 151, láms. 209, 210).

- Kalathos de San Miguel de Liria, conteniendo un ciervo, con oficio muy tosco (Pericot, 1979, 156, lám. 224).

- Vasijas de San Miguel de Liria, con varios ciervos machos y hembras (Pericot, 1979, 160, 161, láms. 233, 236).

- Kalathos de Cabezo de Alcalá, Azaila, Teruel (Fig. 22). La pintura comprende una cierta cantidad de animales, entre los que destacan los cérvidos. $\mathrm{E}$ intercalados numerosos signos geométricos, incluyendo rosetas de cuatro pétalos, que probablemente tienen un significado que va más allá de lo decorativo (García-Gelabert) (Pericot, 1979, 234,235, láms. 375, 376).

- En un ejemplar de Cabezo de la Guardia, Alcorisa, Teruel, hay una nutrida exposición de animales, entre ellos ciervos de complejas cuernas (Pericot, 1979, 256 lám. 412).

- Y en un kalathos de Castelillo de Alloza, Teruel, carniceros atacan a una cierva (Pericot, 1979, 257, lám. 415).

\section{EL CIERVO EN ESTELAS FUNERARIAS DEL ÁREA ÉTNICA INDOEUROPEA}

Relacionadas con las circunstancias de la muerte, evidentemente son las estelas funerarias, propias de los pueblos peninsulares de etnia indoeuropea, al menos no se han hallado en piedra en el área ibera. Las mismas, o delimitan el lugar de deposición de los restos mortales de los difuntos, o recuerdan a los mismos, sin que tengan, exclusivamente, la función de marcadores del enterramiento.

En estas estelas, las decoradas todas tardías, pues contienen epigrafía y ésta es latina, aunque una parte de los nombres de los difuntos son de inequívoca procedencia peninsular nativa, hay representada una cierta cantidad de figuras vegetales, animales y geométricas, generalmente incisas. Son componente del bagaje espiritual celta anterior a la dominación romana, aunque las estelas a las que nos referiremos están fabricadas en una época en la que la presencia de la Metrópoli en la Península, Hispania, está definitivamente consolidada desde siglos atrás. No obstante, insistimos en que los grafismos constituyen una completa y compleja pervivencia de las creencias de los pueblos conquistados. Mas se ha de recordar que, en parte, tales creencias también se hallan enraizadas en el núcleo central de la ideología religiosa de los romanos, por ser éstos componentes del mismo tronco racial indoeuropeo que los celtas hispanos. Destaca, entre la iconografía, la astral, sobre la que trabajamos actualmente (García-Gelabert). Y otros diversos signos de difícil interpretación: arquerías, escuadras, cruces, torques, etc. $Y$ plantas perennes, escasas y repetitivas: la hiedra, y unos arbolillos, que parecen ser de la familia de las coníferas, consistentes en un tallo del que salen trazos oblicuos. $Y$ animales: ciervos, caballos, jabalíes, bóvidos, y poco más. Los elementos astrales indudablemente tienen un claro vínculo con un universo espiritual, inmaterial, cuya naturaleza no llegamos a aprehender. Las plantas, por ser de hoja no perecedera, aparentemente no mueren, así pues pudieran aportar esperanza sobre la pervivencia de la vida, una vez el cuerpo desaparece. Los demás signos, asimismo, deben tener una correspondencia directa con las ideas de permanencia más allá de la vida terrestre. Pero, ¿tienen también los animales un significado en relación con el Más Allá? ¿Son animales conexionados con la muerte? ¿Con qué sentido? Aquí solamente nos referimos, como es la norma seguida, a los cérvidos, porque con relación al caballo, en muchos casos ya domesticado, y/o criado en el seno de las yeguadas, que pastaban al aire libre, y a cuyos ejemplares había que domar y no cazar, es otra versión, que desarrollamos en M.P. García-Gelabert y J. M. Blázquez (2006, 77-123). Argumentamos en la dirección de solamente una o dos teorías de trabajo.

He ahí algunas de las estelas, la mayor parte, si no todas, de la mitad norte peninsular, 
acerca de las que no agotamos, ni mucho menos, el repertorio, en las que el ciervo es el mamífero representado bien único, bien con otros animales, vegetales y/o signos varios:

- En el registro inferior de una estela funeraria, doble, bajo la epigrafía, que hace mención a dos personas Amma o Ammius y Valeria Basilia, hay una cierva con su cría, paradas y mirando hacia la derecha. Los ejemplares están constituidos con trazo firme, economía de líneas e ingenuidad en las figuras y, pese a ello, son fácilmente identificables. En la cabecera destacan fuertemente dos ruedas solares de seis radios curvos (García y Bellido, 1958, 155-156, figs. 3-4) (Fig. 23). La estela es de procedencia concreta desconocida, aunque de la región portuguesa de Belem, ahora depositada en el Museo Leite de Vasconcelos. Uno de nosotros (Blázquez), la data en el siglo III.

- De Rabanales, Zamora, en el registro central, adecuando la epigrafía al cuerpo del animal, se encuentra bajo aquélla, y sobre dos arcos del registro inferior, una cierva parada, hacia la izquierda, con similar expresión estética que las de la estela anterior, pero más tosca en el trazo. De la misma forma, en la cabecera, se determinó un símbolo astral, una rueda solar de doce radios curvos (García y Bellido, 1958, 158, fig. 5) (Fig. 24).

Las estelas vadinienses ${ }^{10}$ son las más prolíficas en figuraciones zoomorfas, siendo el animal preferido en las mismas el caballo, en diversas actitudes. Aparecen en la cabecera o en el registro inferior. Pueden encontrarse solos, en pocas ocasiones y, más a menudo, acompañados de arbolillos, torques, hojas de hiedra, cruces, y algún que otro animal, como jabalí y ciervo, siempre con escasa complejidad en cuanto a estructura compositiva. No hay hechos de caza (Rabanal y García Martínez, 2001, 431):

- La estela funeraria de Beleño, Ponga, Asturias, consistente en un canto apenas sin taIlar, datada en el siglo III (Blázquez), recoge bajo la inscripción, con enorme sobriedad en el trazo,

10. La población de los vadinienses, pastores en gran medida, se sitúa, según M.A. Rabanal Alonso y S. M. García Martínez $(2001,430)$ a ambos lados de la cordillera cantábrica, en la intersección de las provincias de Asturias, Palencia y León. Vadinia es ciudad citada por Ptolomeo (II, 6, 50). Se desconoce su localización. Las estelas funerarias vadinienses son muy características, generalmente consisten en grandes piedras, apenas sin tallar, alisadas en la zona de la inscripción y de la decoración, éstas incisas. Los dedicantes y los difuntos son indígenas. Las inscripciones vadinienses guardadas en el Museo de León son unas treinta.
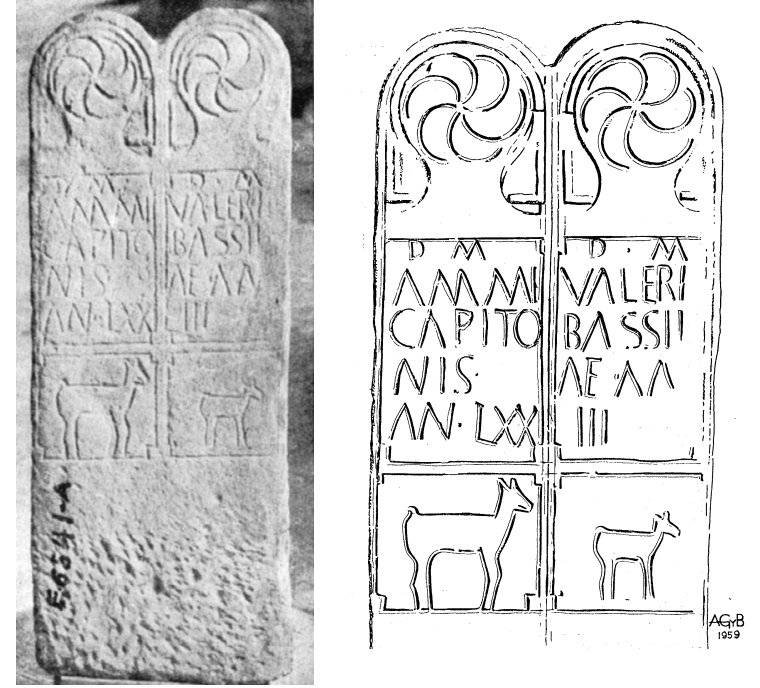

Figura 23: Estela funeraria depositada en el Museo Leite de Vasconcelos (Foto y dibujo García y Bellido, 1958).

entre dos arbolillos, un ciervo con la lengua marcada al exterior, alta cornamenta, y detrás, según A. García y Bellido (1957, 132-134, figs. 20-22), un lobo que persigue al ungulado, y según uno de nosotros (Blázquez), un caballo de menor tamaño . Y hay una peculiaridad, en el cuerpo del segundo animal, sea caballo o lobo, se ha reflejado el nombre del difunto, más la palabra BEA. Por encima y por debajo de estos grafismos hay dos animales inacabados, y sobre la inscripción un puñal de antenas (Fig. 25).

- En una estela funeraria, empotrada, al menos hasta la segunda mitad del siglo XIX, en

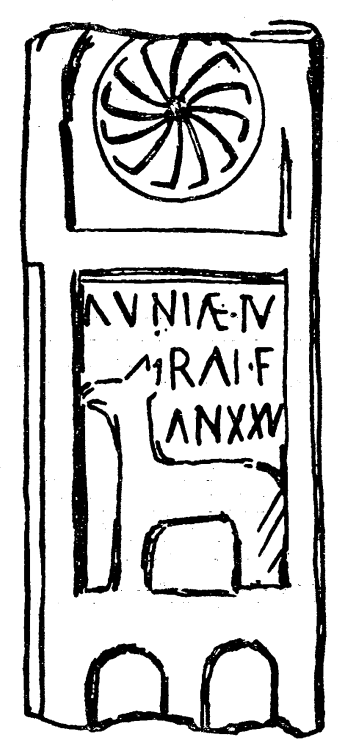

Figura 24: Estela funeraria de Rabanales, Zamora (Según Gómez Moreno, en García y Bellido, 1958). 


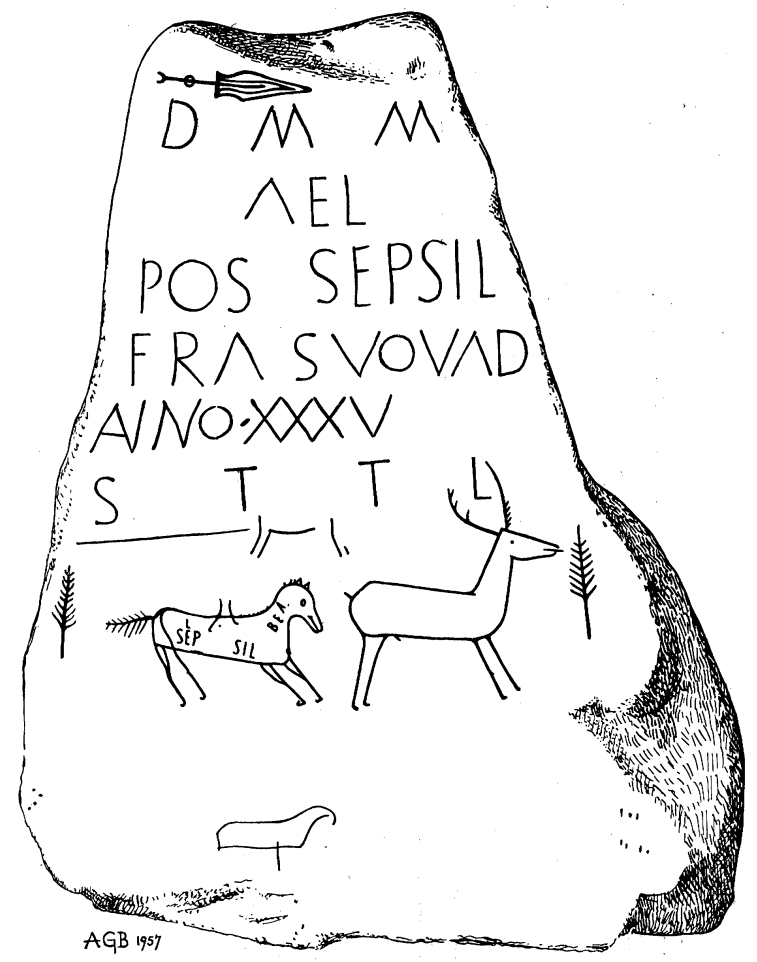

Figura 25: Estela funeraria, Ponga, Asturias (Dibujo García y Bellido, 1957)

la muralla de León, y ahora en el Museo de esta ciudad, bajo la inscripción se representan, en relieve, en marcha hacia la derecha, un jabalí, una cierva de alto cuello, y su cría, mamíferos, todos ellos, idóneos para la caza. Los autores del Corpus opinan que los animales podrían corresponderse con las tres personas referidas en el texto epigráfico (Rabanal Alonso, García Martínez, 2001,250 ). En la cabecera hay tres pequeñas ruedas solares de seis radios curvos. Una posibilidad para estas grafías animalísticas sería la relativa a que se estén señalando las aficiones cinegéticas del varón adulto, al que le fue erigida la estela, Lucretio Proculo (aparece en la dicha inscripción junto a otros dos miembros de la familia, su mujer, Valeria Amma, y su hijo, Lucretio Proculo). La estela ha sido fechada en el siglo II (Rabanal y García Martínez, 2001, 249-250, n. 19, lám. XLVIII.3).

Uno de nosotros (Blázquez) es partidario de que, efectivamente, los équidos, los cérvidos, los jabalíes tienen un carácter funerario, un carácter apotropaico. Desde luego las estelas funerarias están cargadas de simbología, eso es indudable. Pero sencillamente, en estas figuraciones, y para esto no hay que ir muy lejos en la argumentación, el caballo, y los animales de bosque caducifolio, ciervo y jabalí, además de algún otro que no está señalado, eran los predilectos de los hombres cazadores de las tribus norteñas, meseteñas, de todas las tribus peninsulares, en fin. Los mismos cifraban su valía personal, en parte, además de en la guerra, en la caza. Eran hombres que, a través de sus gestas, se les consideraba por sus congéneres más y mejor. Por esto es factible que fueran representados en sus estelas mortuorias aquellos seres del bosque, que para ellos eran los estimulantes más activos de su propia potencia; $y$, por otro lado, eran los sujetos de sus preferencias cinegéticas mientras vivían. En algunas de las estelas funerarias de Celtiberia se enaltece (digamos se heroiza), de igual manera, al fallecido, representando sus hazañas en operaciones bélicas (hombres prisioneros y/o muertos por su brazo) mediante una fórmula metafórica: por medio de caetrae (estelas de Clunia, Burgos), o por medio de lanzas (estelas de Calaceite, Teruel) -las de los vencidos-, o por medio de sucintas escenas de lucha (Lara de los Infantes, Burgos). En resumen, era un procedimiento para exaltar y agasajar al difunto, constituyendo la extensión de los elogios funerales verbales sobre la piedra y para la posteridad (García-Gelabert).

Extrañamente nunca se expresan, en estelas funerarias, animales depredadores, como el oso, el lobo, el lince, etc. Y eso que la captura de estos animales salvajes, sobre todo la del oso, tuvo que ser considerada una gran gesta. A los mamíferos dichos se los cazaba, por lo menos, para eliminar peligros para hombres y ganados, para conseguir la cabeza como trofeo, y la piel, curada, para utilizarla como envoltura, como túnica $u$ otras aplicaciones. Probablemente se organizaban partidas en las que participaba una cierta cantidad de varones de un poblado, o de un territorio, lo que minimizaba el papel individual, aunque, empero, siempre pudieron destacarse algunos cazadores. Bien, de una forma $u$ otra no se sabe el por qué no aparecen en estelas.

El bosquejo de una función terrenal, en general habitual, del desaparecido o desaparecidos, pudiera resultar desde nuestra perspectiva actual frívola, teniendo presente la seriedad trascendente de la cabecera y, cómo no, del asunto por el que se levantó el monumento. Pero, véase como en estelas funerarias, concretamente romanas, por citar un modelo ilustrativo, se hace mención a la ocupación realizada en vida por el difunto; y, en otras, por la añoranza, por la adhesión hacia los fallecidos, o porque así lo quisieron ellos, se apuntan determinadas actividades 
de recreo o de otro cariz, desarrolladas en la tierra por aquéllos.

Sigamos, ¿por qué no puede conjeturarse, como hipótesis añadida, que esos cérvidos, que esos jabalíes, que esos caballos, que esas apenas esbozadas acciones bélicas, que esos símbolos de hazañas guerreras realizadas (caetrae, lanzas, manos cortadas), tenían un significado mágico, de tal forma que, plasmadas en las estelas, se trasponían al lugar a donde iba el ánima del difunto, cualesquiera que fuese su calidad. Lugar en el que, de acuerdo con las creencias propias, por medio de la imagen en la piedra (también debieron existir estelas de madera, deshechas), y las consiguientes fórmulas, plegarias, exorcismos, ritos, sacrificios, etc., podía llegar a rememorar, los goces y honores que conllevaron en su mundo terrenal. O que el ánima del difunto, si es que visitaba la tumba, acerca de ello evidentemente siempre hipotetizamos, y sin base alguna, se recreaba contemplando a los animales, que en su día cazó, a los enemigos que abatió, las lides en las que participó?

Así pues, quien traza estos supuestos de trabajo (García-Gelabert) no es partidaria, de que precisamente el ciervo, el sujeto del estudio actual, tenga, específicamente en las estelas, calidad funeraria. Evidentemente, claro está, por el hecho de su presencia, grabada o en relieve, en un soporte de tal suerte, cual es la estela, ya se reviste de un carácter en relación con la muerte, pero nada más.

Esta teoría, esbozada en breves líneas, quien la afirma no la hace extensiva al sentido de las esculturas de ciervos, que presiden las grandes sepulturas de una civilización distinta, a la de las tribus indoeuropeas, aunque contemporánea en su evolución general. Civilización que se halla situada, como la de los pueblos de procedencia indoeuropea, en fechas anteriores a la conquista de Iberia por Roma, la ibera. A tales ciervos de piedra dedicamos unas líneas en párrafos anteriores. Ya indicamos su significado en aquellos monumentos.

\section{EL CIERVO EN LOS TEXTOS}

Además del cierto protagonismo de los ciervos en el mito de Habis, sobre el que tratamos en el apartado "El ciervo en la toréutica orientalizante de la Edad del Bronce Final, subapartado a) Jarros", este ungulado hembra aparece como héroe principal en otro texto, aludido repetidamente. Sale fuera de los límites cronológicos marcados para este trabajo, mas lo expresamos aquí por lo que tiene de valor, en cuanto a que alrededor de una cierva gira el núcleo del episodio. Pero, sobre todo, porque hay un reflejo, no demasiado luminoso, de creencias autóctonas de siglos anteriores, que generan conductas en los tiempos de la narración. Es el siguiente: un lusitano, de nombre Espano, regaló una cervatilla recién nacida al militar y político romano $\mathrm{Q}$. Sertorio.

Y cuenta Plutarco (Sert. 11): "Como le llamasen, pues, los lusitanos, abandonó el África, y poniéndose al frente de ellos, constituido su general con absoluto imperio, sujetó a su obediencia aquella parte de la España, uniéndosele los más voluntariamente, a causa, en la mayor parte, de su dulzura y actividad, aunque también usó de artificios para engañarlos y embaucarlos. El más señalado entre todos fue el de la cierva que dispuso de esta manera: Uno de aquellos naturales, llamado Espano, que vivía en el campo, se encontró con una cierva recién parida que huía de los cazadores; y a ésta la dejó ir; pero a la cervatilla, maravillado de su color, porque era toda blanca, la persiguió y la alcanzó. Hallábase casualmente Sertorio acampado en las inmediaciones, y como recibiese con afabilidad a los que le llevaban algún presente, bien fuese de caza, o de los frutos del campo, recompensando con largueza a los que así le hacian obsequio, se le presentó también este para regalarle la cervatilla. Admitióla, y al principio no fue grande el placer que manifestó; pero con el tiempo habiéndose hecho tan mansa y dócil, que acudía cuando la llamaba, y le seguía a doquiera que iba, sin espantarse del tropel y ruido militar, poco a poco la fue divinizando, digámoslo así, haciendo creer que aquella cierva había sido un presente de Artemis/Diana, y esparciendo la voz de que le revelaba cosas ocultas, por saber que los bárbaros son naturalmente muy inclinados a la superstición. Para acreditarlo más, se valía de este medio: Cuando reservada y secretamente llegaba a entender que los enemigos iban a invadir su territorio, o trataban de separar de su obediencia a una ciudad, fingía que la cierva le había hablado en las horas de sueño, previniéndole que tuviera las tropas a punto. Por otra parte, si se le daba aviso de que alguno de sus generales había alcanzado una victoria, ocultaba al que lo había traído, y presentaba a la cierva coronada como anunciadora de buenas nuevas, excitándoles a mostrarse alegres y a sacrificar a los dioses, porque en breve había de llegar una fausta noticia" (traduc.A. Sanz Romanillos, J. Ortíz y Sanz, J. M. Riaño) .

$Y$ en un nuevo párrafo sigue escribiendo el de Queronea (Sert. 20): “Andaba muy decaído 
de ánimo a causa de que no parecía por ninguna parte la cierva, y se sentía falto de este artificio para con aquellos bárbaros, entonces más que nunca necesitados de consuelo. Por casualidad, unos que discurrian por el campo con otro motivo, dieron con ella, y conociéndola por el color, la recogieron. Habiéndolo entendido Sertorio, les prometió una crecida suma, con tal que a nadie lo dijesen; y ocultando la cierva, pasados unos días se encaminó al sitio de las juntas públicas con un rostro muy alegre, manifestando a los caudillos de los bárbaros que de parte de Dios se le había anunciado en sueños una señalada ventura, y subiendo después al tribunal se puso a dar audiencia a los que se presentaron. Dieron a este tiempo suelta a la cierva los que estaban encargados de su custodia, y ella que vio a Sertorio, echando a correr muy alegre hacia la tribuna, fue a poner la cabeza entre las rodillas de aquel, con la boca le tocaba la diestra. Correspondió Sertorio con cariño a sus halagos, y aún derramó alguna lágrima, lo que al principio causó admiración a los que se hallaban presentes, pero después acompañaron con aplauso y regocijo hasta su habitación a Sertorio, teniéndole por un hombre extraordinario y amado de los dioses, y cobrando ánimo concibieron faustas esperanzas" (traduc. A. Sanz Romanillos, J. Ortíz y Sanz, J. M. Riaño).

Y Apiano ( b.c.110):"Sertorio tenía una cierva blanca y mansa que estaba en libertad; cuando la cierva no estaba visible, Sertorio lo consideraba de mal augurio para él, estaba malhumorado y permanecía inactivo, aunque era objeto de burla por sus enemigos por causa del asunto de la cierva. Sin embargo, tan pronto como se la vio en plena carrera a través del bosque, Sertorio salió de su postración y, al punto, como si le ofreciera a ella las primicias de un sacrificio, sostuvo una escaramuza contra sus enemigos..." (traduc. A. Schulten).

Otros autores que hacen alusión a esta historia son Frontino I, 11,13; Aulo Gelio, NA XV, 22 y Valerio Máximo, I, 2,4 y 3,5.

Q. Sertorio creía, o mejor dicho, hacía creer, que la cierva blanca era un don de Artemis/Diana ${ }^{11}$. Por el texto se desprende que el político romano era más que incrédulo al respecto de las cualidades del animal. $Y$ con seguridad, a pesar de carecer de apoyo textual, Artemis/ Diana, encubría el nombre de una diosa lusitana.

11. La divinidad itálica Diana muy pronto fue identificada con Artemis, siendo tan profunda su helenización que resulta difícil determinar los rasgos verdaderos de la primitiva diosa latina (Falcón Martínez et al., 1980,179).
Deidad con las mismas características que la griega Artemis, que eran las de la latina Diana, aquélla una de las grandes diosas de las fuerzas naturales. Artemis, hija de Zeus y Leto y hermana gemela de Apolo, nacida en Delos, fue diosa cazadora por excelencia y protectora de la fertilidad de los animales, sobre todo de la de los ciervos. No es extraño que entre los lusitanos fuera adorada la misma diosa indígena que entre sus ascendientes de tiempos atrás, allá por la época del Bronce Final, aquellos ascendientes que depositaban en el interior de las tumbas de sus jefes jarros y thymiateria con figurillas de ciervos: la ancestral Señora de los Animales, la Señora de las Fieras, como también Artemis fue llamada por Homero (II. XXI, 470-507) ${ }^{12}$; y que el ciervo, seguimos Ilamando la atención en su adjetivación como rey del bosque, fuera igualmente en época protohistórica tardía, como lo fue tiempos atrás considerado el animal sagrado de la diosa. Todos los conceptos, todas las divinidades de los panteones de religiones primitivas se repiten. Este aserto, que parece excesivamente simplista, lo es en cuanto a la frase literal, pero no en el contenido. Es así, porque todos los pueblos primitivos, en un medio ambiente aproximadamente similar, o incluso desigual, tienen similares carencias $\mathrm{y}$, por tanto, mediante complejas elaboraciones, crean los dioses que tienden a remediarlas. $Y$ bien, el caso es que Plutarco, por el manifiesto desagrado de los refinados escritores grecolatinos hacia los vocablos peninsulares, no le da a la diosa que, según $Q$. Sertorio, envió a la cervatilla, su nombre propio lusitano, sino los que conoce, Artemis/Diana ${ }^{13}$. Porque, definitivamente, Q. Sertorio, cuando se refería ante sus soldados peninsulares a la cierva blanca, no iba a manifestar"es un presente de Artemis/Diana". Por muy aculturados que estuvieran, que ya lo estaban en el siglo I a.C., poca religiosidad podían inspirarles a los rudos lusitanos las refinadas y lejanas Artemis/Diana. En cambio, si atenderían al señuelo, en el caso

12. Igualmente es citada en el siglo VIII a.C. por Hesíodo (Teog. 918). A ella está dedicado un himno homérico, y otro de Callímaco, y es recordada por Apolodoro en su Biblioteca (I, 4,1; VI, 2,5; 4,3; III, 4,3; 8,2). Artemis persigue a los ciervos con su arco, lucha contra los Gigantes e interviene en el mito de Hércules, el cual recibió de Euristeo el encargo de buscar el ciervo de cuernos de oro que estaba consagrado a la diosa.

13. Acerca de la resistencia de los escritores grecolatinos a escribir nombres autóctonos, al parecer de grafía y pronunciación para ellos muy groseras, muy ordinarias, cfr. nuestro artículo (García-Gelabert y Blázquez, 2006, 9092). 
de que $Q$. Sertorio adujera que la diosa, cuya denominación desconocemos, la diosa propia lusitana, a la que aludiría con el apelativo con que la conocían los nativos (a sus compatriotas la nombraría como Artemis/Diana), le había otorgado a él, a un romano, el don de uno de sus animales preferidos. $Y$ al respecto del discurso de Plutarco, abundando acerca de la no expresión de la designación de la diosa lusitana, teniendo en cuenta, como él mismo opinaba "no creemos que los dioses sean diferentes en las diversas naciones" ¿para qué entonces manejar nombres diversos a los por él conocidos, si con los nombres familiares podía referirse a los dioses de los hispanos, aunque fueran nombrados por aquellos hombres de otras lenguas con otra dicción, y más teniendo presente que él escribía no para los lusitanos, sino para romanos y griegos doctos? $\mathrm{O}$ incluso, siendo como fue un personaje nacido hacia los años 46,50 de la Era (murió hacia el 120), y que tomó datos de archivos y bibliotecas para sus obras históricas, en el transcurso por lo menos de dos estancias en Roma, haya obviado datos que le pudieran parecer superfluos, como las designaciones de los nombres propios de unos dioses indígenas, de los ya remotos tiempos en los que las viejas tribus peninsulares eran libres. Estas tribus a la sazón, si no absorbidas espiritualmente por Roma, en razón de la fuerza de su cultura superior, sí soterradas su religión, tradiciones, costumbres, etc., al menos en la documentación que él manejó. Resumiendo, el nombre lusitano no importaba, importaba la esencia de la diosa en cuestión.

En este episodio, -sabiendo de las estratagemas empleadas por $Q$. Sertorio a lo largo de su carrera como soldado y político, su veracidad entra dentro de lo posible-, la naturaleza del ciervo no tiene nada que ver con la funeraria. Pero sí incide en algo que escribíamos más atrás: que por ser uno de los animales asimilado a una diosa, aquí es patente que lo es de la Señora de la Vida y de la Muerte en su soberanía como diosa de los bosques, de sus habitantes, de la fecundidad y de la vida, en fin el ciervo significaba para los nativos protección en el más amplio sentido. De ahí que la atribución de un carácter oracular a la cierva por parte de Q. Sertorio, fuera perfectamente captado y admitido por aquellos soldados de Hispania o por aquellos civiles con los que tenía contacto, y que no estaban con él en connivencia con respecto al engaño.

$Y$ ya que aludimos, bien que someramente, cual es la línea de este trabajo, a Artemis, en su aspecto de diosa cazadora, y especialmente vinculada a una de las más gratas piezas de caza mayor en bosque, el ciervo, citamos la aparición de la diosa y de los ungulados en algunos mosaicos hispanos bajoimperiales, como:

- El hallado en las excavaciones de la Granja José Antonio de Valladolid, del siglo III. En él Artemis se presenta con tocado de diadema, rayada de blanco, negro y ocre, a modo de plumas y pelo negro recogido. Está en actitud de sacar, con la mano derecha, una flecha del carcaj, y sostiene el arco con la izquierda. A este lado se perfila un ciervo que parece mirarla (Rivera y Wattenberg 1953, 143 ss.; Wattenberg, 1959, lám. XIV, 1-3; idem, 1962, 35 ss.; idem, 1963, 246 ss.; idem, 1964, 115, ss.).

- Una Artemis cazadora era el tema central del perdido mosaico, de finales del siglo II, procedente de Villabermudo, Palencia (Palol, 1963, 246 ss.). En él la diosa dispara el arco a un ciervo, que corre al fondo de la composición. La hija de Zeus gozó de especial predicamento entre los musivarios hispanos, quienes representaron diversos mitos, en los que ella es destacada como figura central, remitimos a la amplia bibliografía sobre el tema.

La predilección por Artemis en los mosaicos fue debida, en gran medida, al enorme entusiasmo que sentían por la caza los domini hispanos que hacían los encargos a los musivarios $^{14}$. Estas figuraciones de Artemis en los mosaicos quedan fuera de toda significación simbólica en correspondencia con las pretéritas creencias de los miembros de las tribus peninsulares prerromanas en relación con el ciervo, esto es obvio. A nuestro parecer consisten, sencillamente, en motivos decorativos del gusto de los domini cazadores, versados en la mitología grecolatina ¿Y qué mejor que contemplar en sus suelos escenas de caza protagonizadas por la diosa cazadora y por los animales cuya fecundidad cuidaba (de cuando en cuando para cazarlos)?

14. Los hispanos y después los hispano romanos, estuvieron muy apegados a las actividades cinegéticas, y se consideró un rasgo típico de su carácter, como lo indica la Historia Augusta (Trig.Tyr. 30), de finales del siglo IV, con ocasión de hablar de la inclinación hacia la caza de Zenobia, la reina de Palmira. Adriano joven, estando en Itálica, pasaba gran parte del día cazando, por lo que su padre adoptivo, Trajano, hizo que se marchara de Hispania (SHA vit. Hdr. 39). Esta afición está confirmada en los tondos relicarios del arco de Constantino, que muestran diferentes cacerías del emperador. 


\section{EL CIERVO EN RITOS PROFANOS}

En actos profanos realizados en Roma y sus territorios, incluyendo, cómo no Hispania, el núcleo central de una serie de ellos consistía en cubrirse con pieles de mamíferos poderosos, con defensas, como ciervos, cápridos, bóvidos. No pudo ser menos al respecto de la extensión de ritos romanos a sus provincias, puesto que en todo el Imperio existía una uniformidad, al menos superficial.

Es posible que se tratara de la continuidad de rituales ancestrales, en relación con prácticas sagradas, de solemnidades religiosas mágico simbólicas de fecundidad, desvirtuadas a través del tiempo por la evolución propia interna de las civilizaciones. O sencillamente tuvieran un origen profano directamente en el seno del pueblo; ya argumentamos más atrás, acerca de este extremo, mas el análisis sale fuera de los límites de esta disertación. En las festividades religiosas primigenias posiblemente uno de los motivos de utilizar especialmente las pieles de aquellos animales estribaba, en que por sus características físicas, en su relación con la manada correspondiente, hacían alarde de un vigor sexual muy notable. Tal fue, y hasta el punto de que, concretamente al toro, se le consideró, desde tiempos neolíticos, como el ser fecundante de la Diosa Madre de la Naturaleza, de la diosa suprema, al parecer, del panteón rudimentario politeísta neolítico. $Y$ en cuanto al ciervo no debió irle a la zaga, sobre todo en el espacio religioso sexual reproductor de los grupos humanos depredadores y cazadores. Y de ahí, por múltiples rumbos ignorados, fue transmitida su asimilación a la diosa primigenia.

Volviendo a las ceremonias civiles aludidas en el primer párrafo de este epígrafe, las mismas consistían, en términos generales, en que las gentes del pueblo disfrazadas de tal guisa, festejaban, en una especie de baile de máscaras desenfrenado, el tránsito de un año a otro. Tratándose de expansiones bulliciosas en relación con el Año Nuevo habían de tener un claro matiz mágico sexual. Así es, puesto que ya en pleno corazón del invierno hablamos de un tiempo en el que comienza a apuntar la renovación de la vida en la naturaleza; el ambiente es, pues, pletórico, porque empieza a brillar nuevamente la savia en la superficie de la tierra, en los bosques, en los campos, después de la oscuridad y vaguedad invernal.

$Y$ pudiera ser que se atribuyera a los animales, con cuya envoltura una cierta multitud se vestía, virtudes fecundantes hacia la Madre Tie- rra, que pronto va a dar sus frutos, porque, por ejemplo, los cereales ya han empezado a señalarse. Este proceso intelectual surgiría de manera implícita, y no pensada, por algún proceso atávico, como producto, reincidimos en la idea, de la herencia de ceremonias religiosas anteriores. Por ello mismo, recalcamos, ciervo, toro, macho cabrío, tenían que ser considerados símbolos fálicos, y de ahí el que los festejos, secularizados, se desarrollaran en un entorno de desenfreno, muy parecido al de los carnavales, que, por otro lado son vestigios de solemnidades de fechas viejas, transformadas a través de los años. Eran prácticas lúdico/religiosas como, entre otras, las saturnales, dedicadas al remoto dios itálico Saturno, de las que tal vez, derivarían, en parte, los dichos carnavales. Aquéllas, las saturnales, debieron tener en origen un carácter agrario, y para la ocasión en que ya se escribe acerca de ellas, habían adquirido un tono licencioso, en el que era de destacar la inversión de las clases sociales.

Las fiestas de Año Nuevo eran de cumplimiento en la Hispania romana bajoimperial, y elementalmente antes. Pero ello no implica que fueran una pervivencia de los ritos sagrados de las tribus peninsulares iberas o celtas, 0 anteriores, aunque ¿contenían matices de los mismos?, tal vez. Pero fundamentalmente ha tenerse en cuenta la aculturación por parte de Roma. Aunque bien es verdad que el terreno estaba perfectamente abonado, porque en la Península Ibérica, desde los más lejanos siglos prehistóricos, el ciervo -dejemos de momento al toro y al macho cabrío-, por su abundancia, por su tan repetida majestuosa estampa, fue considerado, porque lo era, como uno de los animales emblemáticos del bosque, y de enorme resistencia sexual. Los machos, no todos, cuando se hallan en celo, cubren, casi en solitario, a un alto número de hembras. $Y$ tal vez los primitivos chamanes revestidos con su piel, y cabeza, recreando la potencia del animal, de la que mágicamente se hallaban imbuidos, por introducirse en la dicha envoltura, celebrarían ritos de caza, y con el tiempo ritos de fecundidad hacia las cosechas y hacia los animales domésticos. Véase el supuesto hombre religioso de Trois Frères (Fig. 2), cubierto y enmascarado como si se tratara de este animal gregario. Acerca de él, una teoría bastante plausible es la de que está desarrollando un ritual, que tendría que ver, o con la caza, o con la proliferación y/o captación de la fauna del bosque. No queremos indicar, con este dato, que las danzas chamánicas organizadas en el seno de las tribus prerromanas, y los rituales agrarios inherentes a 


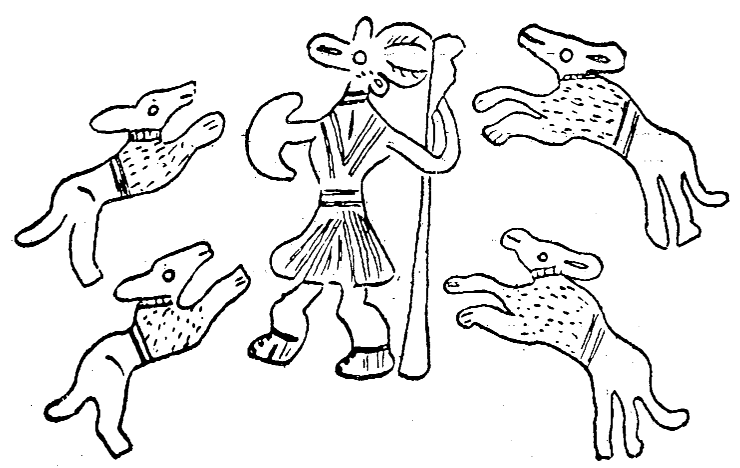

Figura 26: Dibujo de la escena de una vasija de TSH, Bronchales, Teruel (Dibujo P. Atrián, en García y Bellido, 1958).

la religión romana, desciendan directamente de las danzas sagradas del Paleolítico; queremos indicar, simplemente, que las dichas danzas sagradas, en pro de la fecundidad, son tan viejas como el hombre del Paleolítico, aquí Superior. Y posiblemente, en tiempos atrás, en los que no hay grafismos en las cuevas, en los periodos iniciales en que el hombre depredador comienza a ser consciente de que depende de fuerzas inmateriales, también se llevaban a cabo. Ciertamente las ceremonias de fecundidad, porque es necesario contar con la aquiescencia de seres excelsos lejanos para conseguir buena comida, están implícitas tanto en el hombre depredador como en el hombre sedentario de todos los tiempos y de todas las civilizaciones primitivas.

Sigamos con las fiestas profanas. Acerca de las dichas el obispo de Barcelona, Paciano, de la segunda mitad del siglo IV (murió en el año 390), recoge la costumbre popular del cervulum facere (hacer el ciervecillo), en un opúsculo, perdido, Cervus. De él se tiene referencia a través de la obra de San Jerónimo, De viris illustribus (cap. 106), escrita hacia el año 392: "Paciano, obispo de Barcelona, en las faldas del Pirineo, de correcta elocuencia, y tan esclarecido por su vida como por su dicción, compuso varios opúsculos, entre los cuales el Cervus y contra los novacianos. Murió en la extrema ancianidad, bajo el emperador Teodosio". Paciano, en Cervus, ataca juegos, que el llama paganos, en los que se sigue la tradición, manifestada más arriba, de caracterizarse de ciervo en las fiestas celebradas a finales del año o principios del siguiente. En otro de sus escritos, Paraenesis (cap. 1), se refiere nuevamente a la práctica pagana de cervulum facere, como abominable.

Estos actos, determinados por Paciano y por otros autores, mencionados más abajo, eran fiestas de anarquía (controlada o no tanto), fiestas inmorales. Y por tal, y porque precisamente se achacaba la perversión de las mismas a la mala influencia de la antigua religión oficial romana, de la que provenían, eran definitivamente condenadas por la Iglesia cristiana, y no sólo por la hispana, sino, según datos que poseemos, por la de la Galia, y a buen seguro por la de otras provincias. Y de estas fiestas, rigurosamente escandalosas, se ocupó el cuarto Concilio de Toledo (633), en cuyo canon 11, se expresa que, por los pecados cometidos en las calendas de enero, debía observarse, a principio de año, un día de ayuno y abstinencia. Son reprobadas en otros concilios, como en el celebrado entre 573 y 603, en Auxerre (Concil. Autissiodorense, en Conc. Aevi Merov., canon I). $Y$ en ciertos escritos, no totalizamos, se cuestiona la propensión a tomar formas de animales en las fiestas y critican la conducta licenciosa del pueblo al respecto de los tan repetidos disfraces y de las provocaciones hacia la Iglesia y hacia las autoridades. Esta animadversión podría deberse, no al hecho estricto del disfraz, bajo el cual se cometían impunemente actos reprensibles, sino porque estas mascaradas pensaban que encubrían, entre otras actitudes, instigaciones contra el orden religioso cristiano: loam. Cr., In. kal. PG.48, 953-62; Epist. Canon 891 A-B, hacia el año 500; Dicta abbat. Primin., hacia el año 700 , cap. 22, p. 175; Cesario de Arles (470-543), (Pseudo-) Augst., Serm. 129, 2; 130; 265, 5; de tempore, 215; Ambr., in Psalm, 41; Vita Eltg., II, 15, y otros. Igualmente el homiliario hispano del British Museum, del ms. "add. 308445", censura la costumbre de vestirse con pieles de animales, siendo una de las nombradas la del ciervo: “¿Qué persona

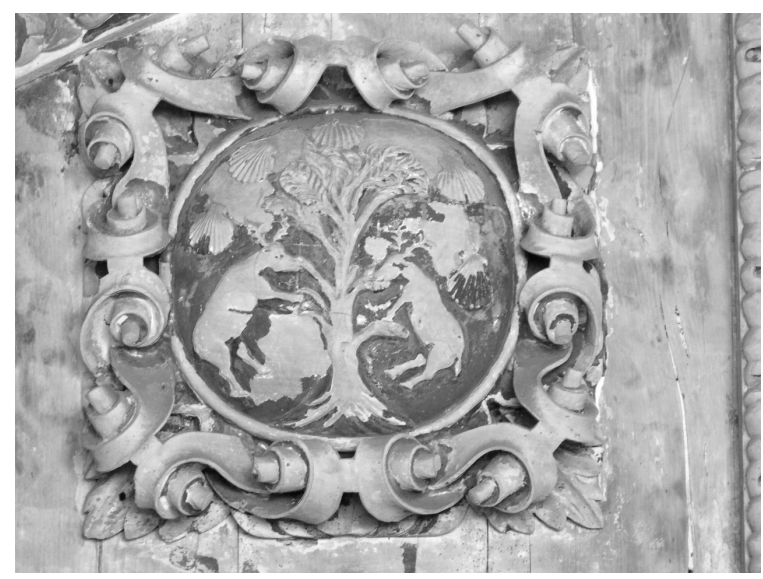

Figura 27: Medallón de la cabecera del altar de la ermita de San Pascual, La Mortera, Tineo, Asturias. 


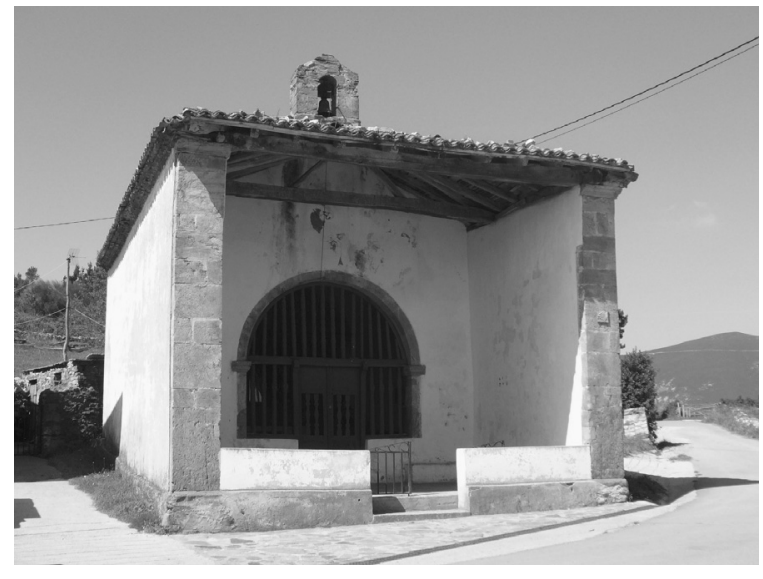

Figura 28: Ermita de San Pascual, La Mortera, Tineo, Asturias.

inteligente podrá creer que se encuentren algunos hombres cuerdos que, haciendo el ciervito, quieran cambiar su aspecto por el de fieras? Unos se visten con pellejos de oveja, otros se ponen cabezas de bestia..."15

Las prácticas lúdicas aludidas es posible que puedan relacionarse con la decoración de un fragmento de TSH del taller de Bronchales, Teruel, al que alude, entre otros, A. García y Bellido (1958, 156, fig.6) (Fig. 26). En él se representa a un individuo con cabeza de ciervo; viste túnica corta y cinturón, calza botas y lleva un gran cayado y escudo. Está rodeado de cuatro perros atacando, o retozando alrededor del personaje.

$Y$ dando un giro rotundo al tema de este apartado, y en realidad y en general, al del trabajo, terminamos ofreciendo al lector una ilustración de cómo la iconografía del ciervo, asimismo, ha sido utilizada por la Iglesia de Cristo. Los caminos para su manejo y la simbología que contiene, quedan fuera de la temática objeto de nuestro estudio. He ahí una muestra en el medallón del lado izquierdo de la cabecera del altar de la ermita dedicada a San Pascual, situada en la localidad asturiana de La Mortera, Tineo, en pleno Camino de Santiago (Figs. 27 y 28). Obsérvese cómo el árbol que sirve de eje a los dos ciervos rampantes está rodeado de las características conchas de peregrino. La ermita está datada entre los siglos XVI y XVII.

15. Otros documentos en J. Caro Baroja, 1965. San Isidoro de Sevilla resume los datos que sobre la costumbre de disfrazarse de ciervo se hallan desperdigados en los santos padres (De eccl. off., l, 541).

\section{CONCLUSIÓN}

Cabe la posibilidad de que existiera el culto al ciervo en la fase final del Bronce y posiblemente desde tiempos atrás, entre las tribus del suroeste meridional y sur de Extremadura y Portugal. Ahora bien, dicho culto no debió ser creado porque fuera considerado un dios, sino el animal sagrado de una divinidad, probablemente de gran magnitud, señor o señora de la vida y de la muerte. $Y$ de ahí la causa de que precisamente el animal a ella ligado, -hay que pensar en las posibles peculiaridades de estas religiones, esgrimiendo el sistema comparativo con religiones antiguas o primitivas actuales-, fuera incluido en los ajuares funerarios como protector, digamos por "delegación" de tal ser excelso, éste nunca fue representado por aquellas fechas. El ciervo fue figurado en elementos materiales, parece que rituales, como jarros, thymiateria. Asimismo han aparecido, sin situación determinada concreta, en poblados o lugares sacros, figurillas exentas de ciervos, sin que sepamos dónde eran colocadas. Acerca de las mismas, en texto atrás, indicamos que pudieran haber recibido algún tipo de culto, con el mismo significado secundario que el esgrimido en líneas inmediatas superiores. Semejante calidad tuvo el ungulado de referencia en la religión ibera, pero aquí cambia el ritmo de su presencia, no lo contemplamos como parte de los ajuares funerarios o como pequeñas imágenes tal vez de culto, lo contemplamos en los frentes de los monumentos sepulcrales.

En cambio, en la lberia indoeuropea, en las estelas funerarias, bien el ciervo fue revestido de carácter funerario apotropaico (Blázquez), bien junto con otros animales, sencillamente, tuvo un carácter descriptivo, o yendo más allá un carácter mágico en relación con su presencia ante al difunto en actividades cinegéticas en el Más Allá o en el propio sepulcro.

Y corriendo los años y los siglos, el pueblo llano se cubrió con pieles de animales con cuernos, entre ellos de cérvidos, para celebrar el tránsito de un año a otro, quizá recreando, puede que sin tener conciencia clara de ello, ritos sagrados de fecundidad de las viejas religiones de los viejos tiempos. Fiestas de mascaradas que los Santos Padres de la Iglesia de Cristo condenaron.

Pasado el tiempo la Iglesia incluyó al ciervo, no profusamente, en su repertorio iconográfico.

La investigación queda abierta a futuros descubrimientos.

Valencia, septiembre 2007 
Profa. María Paz García-Gelabert Pérez Dpto. de Historia de la Antigüedad y de la Cultura Escrita

Facultad de Geografía e Historia

Avda. Blasco lbáñez, 28

Universidad de Valencia

46010 Valencia

Prof. José María Blázquez Martínez

Real Academia de la Historia

c/ León, 21

28014 Madrid

\section{BIBLIOGRAFÍA}

ARANEGUI, C., JODIN, A., LLOBREGAT, E., ROUILLARD, P. y UROZ, J., 1993: La nécropole ibérique de Cabezo Lucero. Guardamar del Segura, Alicante, Madrid-Alicante.

BALDELLOU, V., 1987: "Arte rupestre en la región pirenaica", VV.AA., Arte rupestre en España, Revista de Arqueología, extra, 66-77.

BERMEJO, J., 1982: Mitología y mitos de la Hispania prerromana, Madrid.

BLÁZQUEZ, J. M., 1975: Diccionario de las religiones prerromanas de Hispania, Madrid.

BLÁZQUEZ, J. M., 1983: Primitivas religiones ibéricas II. Religiones prerromanas, Madrid.

BLÁZQUEZ, J. M., 1993: Mosaicos romanos de España, Madrid.

BLÁZQUEZ, J. M., y REMESAL, J., 1979: La necrópolis del Estacar de Robarinas, J. M. BLÁZQUEZ, Castulo II, EAE 105, 347-395, Madrid.

BERNALDO DE QUIRÓS y F., CABRERA, V., 1982: El arte paleolítico en la Cornisa Cantábrica, Madrid.

CARO BAROJA, J., 1965: El carnaval, Madrid.

CELESTINO, S. y JIMÉNEZ ÁVILA, J., 1996: El Palacio-Santuario de Cancho Roano V. El Sector Oeste, Madrid.

CLARK., G., 1973: Los primeros quinientos mil años. Los cazadores y recolectores de la Edad de Piedra, Los cazadores y recolectores, VV.AA., El despertar de la civilización. Los enigmas de las antiguas culturas revelados, 19-40, Barcelona.

FALCÓN MARTÍNEZ, C., FERNÁNDEZ-GALIANO, E. y LÓPEZ MELERO, R., 1980: Diccionario de la mitología clásica, I, Madrid.

FERNÁNDEZ CASTRO, M.C., 1989: "Acerca de la cierva ibérica de bronce del Museo Británico", Homenaje al Profesor Antonio Blanco Freijeiro, 107-130, Madrid.

GARCÍA Y BELLIDO, A., 1957: "El jarro lusitano de la Colección Calzadilla", AEspA 30, 121-138.

GARCÍA Y BELLIDO, A., 1958: "De nuevo sobre el jarro ritual lusitano, publicado en AEArq. 30, 1957, 121 ss.", AEspA 31, 153-164.

GARCÍA-GELABERT, M.P., 2005: "El trabajo sobre hueso en el Magdaleniense Superior Final del grupo humano de la Cueva del Valle, Rasines, Cantabria. Campañas de los años 1996, 1997, 1998", Zephyrus 58, 111-134.

GARCÍA-GELABERT, M.P. ET AL., 2004: La cueva del Valle, Rasines, Cantabria, España, BAR Internacional Series 1252, Oxford.
GARCÍA-GELABERT, M.P. y BLÁZQUEZ, J. M., 2006: "Dioses y caballos en la Iberia Prerromana", Lucentum XXV, $77-123$

GARRIDO, J. P. y ORTA, E.M., 1978: Excavaciones en la necrópolis de "La Joya", Huelva. II. ( $3^{\mathrm{a}}, 4^{\mathrm{a}}$ y $5^{\mathrm{a}}$ campañas), EAE 96, Madrid.

GONZÁLEZ NAVARRETE, J. A., 1987: Escultura ibérica de Cerrillo Blanco, Porcuna, Jaén, Jaén.

HERNÁNDEZ PÉREZ, M.S., 1987: Arte rupestre en el País valenciano, VV.AA., Arte rupestre en España, Revista de Arqueología, extra, 78-85, Madrid.

HUYGHE, R., 1965: El arte y el hombre, Vitoria.

JIMÉNEZ ÁVILA, J., 2002: La toréutica orientalizante en la Península Ibérica, RAH, Madrid, 2002.

JIMÉNEZ ÁVILA, J., 2005: "De los bronces tartésicos a la toréutica orientalizante. La broncística del Hierro Antiguo en el Mediodía Peninsular", S.CELESTINO PÉREZ y J. JIMÉNEZ ÁVILA (eds.), El periodo orientalizante, vol. II. Actas del III Simposio Internacional de Arqueología de Mérida: Protohistoria del Mediterráneo Occidental, 1089 ss, Mérida.

JORDÁ, F. y BLÁZQUEZ, J. M., 1988: Historia del Arte Hispánico. La Antigüedad. I.1, Madrid.

LUZÓN, J. M. y LEÓN, P. (eds.), 1996: Antonio Blanco Freijeiro. Ópera minora Selecta, Sevilla.

MALUQUER, J., 1981-1982: El santuario protohistórico de Zalamea de la Serena, Badajoz, II, Programa de Investigaciones Protohistóricas V, Barcelona.

MARÍN CEBALLOS, M.C., 2000-2001: "La representación de los dioses en el mundo ibérico", Lucentum XIX-XX, 183 ss.

NEGUERUELA, I., 1990: Los monumentos escultóricos del Cerrillo Blanco de Porcuna (Jaén), Madrid.

NEGUERUELA, I., 1998: Las esculturas del Cerrillo Blanco de Porcuna, VV.AA., Los Iberos. Príncipes de Occidente, 170-171, Barcelona.

OLMOS, R., 1992: Broncística fenicia y orientalizante en el Sur Peninsular y en Ibiza. Una aproximación iconográfica y simbólica, VI Jornadas de Arqueología fenicio-púnica. Trabajos del Museo Arqueológico de Ibiza y Formentera 27, 41-64, Ibiza.

PALOL, P. DE, 1963: "El mosaico de Diana de Villabermudo, provincia de Palencia", BSAA 29, 246 ss.

PERICOT, L., 1979: Cerámica Ibérica, Barcelona, 1979.

RABANAL, M.A. y GARCÍA MARTÍNEZ, S.M., 2001: Epigrafía romana de la provincia de León: Revisión y actualización, León.

RIVERA, S. y WATTENBERG, F., 1953: "Las excavaciones de la Granja José Antonio de Valladolid", BSAA 19, 143 ss.

RODRÍGUEZ DE LA FUENTE, F., 1970: Fauna, t. 5. Eurasia y Norteamérica (Región Holártica), Pamplona.

VÁZQUEZ, J. M., 1987: Arte rupestre prehistórico en Galicia, VV.AA., Arte rupestre en España, Revista de Arqueología, extra, 106-113, Madrid.

WATTENBERG, F., 1959: La región vaccea. Celtismo y romanización en la cuenca media del Duero, Madrid.

WATTENBERG, F., 1962, 1963: "El mosaico de Diana en la Villa de Prado (Valladolid)", BSAA 28, 35 ss.; 29, 246, ss.

WATTENBERG, F., 1964: "Los mosaicos de la Villa de Prado", BSAA 30, 115 ss. 